\title{
DISKURSUS THE MALAYS DAN MALAYNESS : PERSPEKTIF HERMENEUTIKA FILOSOFIS GADAMER*
}

\author{
Irwandra \\ Mahasiswa Doktoral Ilmu Filsafat Fakultas Filsafat Universitas Gadjah Mada \\ wan salayan@ymail.com \\ Misnal Munir \\ Fakultas Filsafat Universitas Gadjah Mada \\ Heri Santoso \\ Fakultas Filsafat Universitas Gadjah Mada
}

\begin{abstract}
Abstrak
Tulisan ini bertujuan untuk mendiskusikan secara informatif-deskriptif dan sekaligus pula kritis-filosofis terhadap dua wacana utama, yaitu The Malays dan Malayness yang dalam konteks sejarab dan dinamika budaya Melayu dikesankan tumpang-tindih, sebingga kerap disalah-pahami. Penggunaan hermeneutika filosofis Gadamer sebagai media dalam menganalisis data dalam kajian ini diharapkan dapat menemukan pemahaman baru terhadap dua tema di atas, utamany a dalam konteks penguatan nilai-nilai dan pembentukan karakter yang berbasis budaya. Pencermatan dan penelaahan yang dilakukan terhadap khazanah budaya Melayu ditemukan bahwa budaya Melayu yang terbentang dalam rentang tiga masa, masa lalu-masa sekarang-masa depan menemukan titik-pijak sebagai tempat dalam penapakan budaya, terutama setelah masuk dan berkembangnya Islam di Kepulauan Melayu-Indonesia. Titik-pijak. yang dimaksud adalah "Pemuncakan Budaya" Melayu yang disebut sebagai fresh culture. "Pemuncakan Budaya" berlangsung secara berterusan dan menjejak di hampir setiap praktek kehidupan dengan tanpa menegasikan pola kepercayaan lama (adat dan tradisi) yang terlebih dahulu masuk dan bersentuhan dengan dinamika kehidupan masyarakat.
\end{abstract}

Kata Kunci: The Malays, Malayness, Hermeneutika Filosofis, "Pemuncakan Budaya” (Fresh Culture).

\begin{abstract}
This paper aims to discuss informatively and critically-philosophically the two main discourses, namely The Malays and Malayness, which in the context of history and the dynamics of Malay culture are suggested to overlap, so that it is often misunderstood. The use of Gadamer philosophical hermeneutics as a media in analyzing data in this study is expected to be able to find new understanding of the two themes above, especially in the context of strengthening values and forming culture-based characters. The scrutiny and review of the treasures of Malay culture found that the Malay culture which stretched in a span of three periods, the past-present-future found a starting point as a place for cultural assessment, especially after the entry and development of Islam in the Malay-Indonesian Archipelago. The intended point is the Malay Culture "which is called the fresh culture. "Culture Appearance" takes place continuously and tracks in almost every practice of life without negating the old belief patterns (customs and traditions) that first enter and come into contact with the dynamics of people's lives.
\end{abstract}

Keywords: The Malays, Malayness, Hermeneutika Filosofis, "Pemuncakan Budaya” (Fresh Culture).

\section{PENDAHULUAN}

Budaya merupakan 'rumah hidup' yang berfungsi sebagai arena dan media bagi manusia dalam berdinamika yang melibatkan dan memperjumpakan segenap emosi dan pikiran, serta diinsafi sebagai bentuk dan identitas berada dan mengada dalam kesemestaan. Budaya, dalam realitasnya pun tidak jarang memiliki intensitas yang berdaya dalam menggerakkan (ke luar) dan sekaligus pula menyatukan setiap komponen ke dalam suatu sistem yang disepakati dan dibangun secara bersama-sama, dan kemudian menjadi anutan dalam bertata-hubung antar dan lintas entitas dalam jalinan jaringan kesemestaan.

Fungsi inilah yang kemudian oleh sejumlah kalangan dinyatakan, bahwa budaya merupakan suatu kekuatan yang memiliki daya rekat dan menjadi dasar dalam memberikan suatu alasan yang bersifat moral bagi pengembangan suatu tatanan masyarakat (Koentjaraningrat, 1989: 190; 2004: 25- 
26; Wildes, 2006: 69), serta dalam menetralisir ketegangan dan konflik yang ada dalam kehidupan masyarakat modern (Arnold, 2006: 71). Potensi yang dimiliki budaya ini, oleh Hallen (2010: 84) disebut sebagai prima facie integrity yang membedakannya dengan sistem pengetahuan pada umumnya.

Budaya dengan demikian, merupakan identitas manusia yang berkemampuan dalam mempertemukan dan menata hubungan antar satu individu dengan yang lain, antar satu kelompok dengan kelompok lainnya, dan bahkan, dalam bentuknya sebagai sebuah sistem budaya (adatistiadat) mempertautkan manusia dengan dan antar realitas, baik yang terindera dan teraba maupun yang hanya dirasa (batin-spiritual) (lihat Koentjaraningrat, 1984: 2, 79). Budaya dalam konteks ini, mengikut apa yang dikatakan oleh Masolo (2003: 31) sebagai ...the indigenous is the whole realm of what constitutes our consciousness.

Pengertian dan potensi yang kompleks ini menempatkan (konsep) budaya sebagai suatu sistem yang memberikan pengaruh terhadap konsep manusia, dan suatu pola budaya akan membimbing pembentukan menjadi seorang individu (Geertz, 1973: 52). Budaya dengan segenap kompleksitas yang melingkupi tanpa disadari mampu merubah dan membertentukan manusia dalam skala yang luas-mendalam, sehingga mengkristal membentuk sebuah identitas yang membedakannya dari suatu kelompok masyarakat (budaya) yang lain.

Sudut pandang ini yang membuat Dr. Radjiman dalam kertas kerja yang disampaikan pada Congres voor Javaansche Cultuur Ontwikkeling (Kongres Pengembangan Kebudayaan Jawa) tahun 1918 berkesimpulan, bahwa "jika pribumi dipisahkan sepenuhnya dan secara paksa dari masa lalunya, yang akan terbentuk adalah manusia tanpa akar, tak berkelas, tersesat di antara dua peradaban" (dalam Lombard, Bagian 1, 2005: 235). Sejalan dengan itu, Syari'ati (1990: 46-47) menjelaskan,

...seorang individu yang tak berkebudayaan akan gampang menerima setiap nilai dan dimensi, menjadi suatu alat dalam genggaman musuh. Jika suatu kebudayaan dipisabkan dari seorang individu, 'Kemanusiaan' maupun ciri-ciri bawaaan etnisnya akan bilang, dan ia berubah menjadi jasad mati yang definisi sempurna dan logisnya adalab = 'berat + tinggi.'

Asumsi budaya yang dibentangkan di atas menjadi alas bagi upaya dalam mencermati dan menelaah kembali kedudukaan budaya hari ini, khususnya yang ditujukan pada budaya Melayu dan terkait dengan dua wacana utama yang menjadi perhatian dalam kajian ini, yaitu The Malays dan Malayness. Pendalilan budaya yang disinggung di atas menjadi semacam sudut pandang dalam 'menggugat' atau sebaliknya, 'meneguhkan' satu di antara dua wacana utama yang dimaksud.

Wacana ini dipandang sebagai dua bentuk pemahaman yang secara prinsip berbeda dan turut berimplikasi pada dua kondisi yang berbeda pula. The Malays kerap dimengerti sebagai 'orang Melayu' yang diidentifikasi melalui faktor genealogis, etnisitas dan kawasan tertentu, sedangkan Malayness memberikan penekanan pada aspek budaya Melayu yang berlaku secara luas (ke-Melayu-an), tanpa harus terperangkap dengan faktor-faktor di atas.

Poin ini menjadi penting disebabkan persoalan budaya -terlebih jika dihubung-kaitkan dengan asumsi budaya yang telah dibentangkan oleh beberapa tokoh di atas- merupakan hal utama dalam setiap arus perbincangan penguatan nilainilai dan pembentukan karakter yang berbasis budaya. Budaya sebagai sebuah identitas yang memiliki kekuatan integratif secara sosial dipandang perlu untuk terus ditelaah dan dicermati, sehingga nilai-nilai yang terkandung dalam suatu budaya dapat menjadi haluan dalam merancangbangun tatanan kehidupan. Pranarka dan Bakker (1979: 21) mengatakan, membangun tata dunia baru pada hakikatnya haruslah dipandang sebagai satu masalah kebudayaan. Sebaliknya, menampik aspek budaya akan berakibat pada kehilangan identitas, dan ini menjadi indikator rusak dan runtuhnya sistem sosial karena keterputusan atau keterpecahan dalam suatu tradisi. Habermas (1988: 4) dalam Legitimation Crisis mengungkapkan, jika generasi yang akan datang sudah tidak lagi mengenali dirinya dalam tradisi masyakat itu sendiri, maka suatu sistem sosial (masyarakat) akan kehilangan identitasnya.

Pada bagian lain disebutkan pula, jika tradisi tidak membangkitkan keinginan untuk menyebarkan nilai-nilai yang ada, maka proses difusi -sebagai usaha dalam mempertahankan tradisi dan bagian dari epidemiologi budayamenemukan titik buntu (Morin, 2016: 52, 148-149). Oleh karenanya, pengarusutamaan terhadap persoalan nilai-nilai atau karakter yang dimiliki oleh budaya Melayu menjadi hal yang penting, dan ini tentu harus mendapat perhatian bersama, terutama 
dalam bingkai khazanah ke-Melayu-an yang membentang dalam rentang tiga masa, masa lalumasa sekarang-masa depan. Kajian ini lebih memberikan perhatian pada aspek ke-Melayu-an, sehingga budaya Melayu mendapatkan 'tempat berpijak' untuk kemudian beranjak mengelola-bina isu-isu stategis yang berkembang dewasa ini.

'Tempat berpijak' akan ditelusuri, diurai dan diungkap melalui pendekatan atau analisis hermeneutika filosofis Gadamer sebagai bagian penting dalam diskursus filsafat secara umum. Analisis ini memberikan porsi yang memadai bagi proses penemuan pemahaman baru yang terbentang dalam khazanah budaya Melayu. Pada titik ini, melalui hermeneutika filosofis diharapkan akan menghadirkan perspektif berharga bagi penguat-kukuhan identitas ke-Melayu-an. Pandangan ini sejalan dengan pernyataan Peursen (2003: 142), bahwa penelaahan terhadap persoalan budaya akan memberikan petunjuk apakah suatu budaya masih memiliki daya hidup yang kuat, atau sebaliknya, bahkan telah lenyap sama sekali untuk kemudian segera akan digantikan dengan kebudayaan lain.

\section{METODE}

Model penelitian yang digunakan dalam kajian ini adalah penelitian kualitatif bidang filsafat dengan bertumpu pada data dokumen sebagai data utama (Kaelan, 2012: 129). Asumsi tentang budaya yang terbentang dan menjejak dalam ragam peristiwa, khususnya yang terangkum dalam khazanah budaya Melayu ditempatkan sebagai sebuah ide filosofis, bukan sebagai ide antropologis, sosiologis, psikologis, dan lainnya. Ide filosofis dipandang sejauh berhubungan dengan hakikat manusia dan mempunyai tempat dalam suatu kerangka pikiran menyeluruh: ontologis, aksiologis, antropologis, mungkin juga epistemologis (Bakker dan Zubair, 1990: 77). Namun demikian, informasi yang diperoleh data antropologis, sosiologis, psikologis dan lainnya menjadi bagian pendukung dalam menyelami dan mencermati fenomena budaya dalam hubungannya dengan identitas ke-Melayu-an.

Data yang diperoleh dianalisis dengan menggunakan hermeneutika filosofis Gadamer yang dalam cara kerjanya menempatkan dan mengarahkan persoalan pemahaman pada level ontologis. Pemahaman, menurut Gadamer (2004: xxvii) tidak hanya salah satu dari berbagai kemungkinan perilaku subjek, tapi sebagai cara menjadi Yang-Ada itu sendiri. Di sinilah hermeneutika mengambil bentuknya dengan menunjukkan dasar menjadi-dalam-gerak YangAda yang mengangkat keterbatasan dan historisitas, dan karenanya mencakup seluruh pengalaman dunia. Gerakan ini tidak terjadi secara tiba-tiba, melainkan menjadi sifat dari hal itu sendiri, sehingga membuat pergerakan pemahaman yang komprehensif dan universal. Orientasi hermeneutika merupakan bagian dari upaya filosofis yang meletakkan pemahaman dalam sudut ontologis.

\section{HASIL DAN PEMBAHASAN}

\section{Perspektif Hermeneutika Filosofis}

Pencermatan terhadap khazanah budaya Melayu yang berkait dengan dua isu utama, The Malays dan Malayness dengan perspektif hermeneutika filosofis dilakukan melalui beberapa tahapan, yaitu pertama, interpretasi yang tidak bersifat arbitrer, melainkan bersumber dan berdasarkan pada data objektif yang ada (Gadamer, 2004: 269-70). Kegiatan interpretasi merupakan gerakan pemahaman dan penafsiran yang selalu diikuti dengan suatu proyeksi (Entwurf), sebuah istilah yang kerap digunakan oleh Heideger (Hardiman, 2015: 121-29, 168). Menurut Gusmao (2012: 102), proyeksi menjadi dasar bagi Gadamer dalam melakukan rehabilitasi terhadap konsep prasangka (Jerman: Vorurteil; Inggris: prejudice), yang memiliki peran penting dalam hermeneutika filsofis. Gadamer (2004: 273) sendiri menjelaskan, bahwa konsep prasangka merupakan tempat pemahaman dan penafsiran, dan dari situlah suatu kegiatan interpretasi dan/atau proyeksi dimulai, suatu kondisi untuk memahami.

Pemulihan terhadap konsep prasangka memberikan petunjuk bahwa seorang interpreter di saat menghadapi sebuah teks tidak bermula dari suatu kondisi tabula rasa, tapi berawal dari sebuah "tempat tradisi" di mana teks didekati, dan inilah yang disebut dengan prasangka dan dipandang sebagai media untuk menuju (masuk) ke dalam sebuah teks (Smith, 1997: 26). Gusmao (2012: 102) menyebut situasi ini sebagai proses dari penafsiran yang berangkat dari suatu prasangka dan terus mengarah pada kondisi kepenuhan (tabula pena).

Pemulihan konsep prasangka memiliki dua sasaran yang ingin dituju, yaitu perluasan dan sekaligus pendalaman atas makna yang ada pada 
sebuah otoritas dan tradisi. Dua sasaran ini menjadi tujuan penting dalam hermeneutika filosofis Gadamer, karena melalui sifat umum yang dimiliki oleh suatu tradisi yang dapat menjadikan masa lalu bertahan dengan ragam kemungkinan pengetahuan historisnya. Dengan demikian, upaya dan proses untuk memahami bukanlah dipandang sebagai tindakan subjektif, melainkan sebagai bentuk partisipasi dengan menempatkan seseorang di dalam proses atau peristiwa tradisi (Gadamer, 2004: 290-293).

Tahapan kedua, holistika yang diarahkan pada dua sisi, yaitu (1) keutuhan dari proses pemahaman dalam suatu kajian dilihat dari bagaimana konsep (kajian) tersebut dapat menerangkan bagian-bagian yang ada dalam kajian yang dimaksud. Pada sisi yang lain (2), keterangan yang diberikan terhadap bagian-bagian sekaligus pula menjelaskan tentang keutuhan konsep yang ada. Pada konteks ini, bagian-bagian tidak lain merupakan satu-kesatuan yang menggamrkan tentang keutuhan suatu konsep. ...we must understand the whole in terms of the detail and the detail in terms of the whole, ungkap Gadamer (2004: 291).

Persoalan keterjarakan waktu dalam konteks hubungan yang timbal-balik, dari keutuhan ke bagian-bagian dan sebaliknya, tidak menyebabkan upaya untuk menghasilkan pemahaman baru dari suatu tradisi (teks) terhambat. Kegiatan interpretasi dalam tahap holistika justru menyiratkan bahwa seorang penafsir tidak berada di luar situasi (sejarah), tapi bersama dan bergerak dalam sejarah dan sekaligus pula tidak melampaui sejarah. Situasi ini merupakan media dalam upaya mengatasi dimensi historisitas dan sebagai bentuk atau cara dalam memahami. Kondisi ini biasanya disebut dengan "situasi hermeneutik" yang dibedakan dari "lingkaran hermeneutik."

Lingkaran hermeneutik merupakan suatu proses (interpretasi-pemahaman) yang berlangsung secara dialogis, terbuka dan komunikatif dengan menggunakan sarana bahasa dan nalar yang bertujuan untuk menelusuri dan menelisik, sehingga sampai pada suatu kondisi "perjumpaan" dengan pemahaman yang mengatasi aspek historisitas. Lingkaran ini, sebagaimana ditandaskan oleh Gadamer (204: 293-294), tidak merupakan lingkaran metodologis, tapi lebih menggambarkan tentang struktur ontologis suatu pemahaman, atau sebagai sebuah gerakan yang mengarahkan seorang penafsir untuk berkumpul bersama sepanjang dan dengan seluruh tradisi pemahaman. Gusmao (2012: 99-100) memaknainya sebagai lalu-lintas pengertian yang mulai di satu titik dan menuju titik lainnya, atau dari sebuah antisipasi untuk sampai pada sebuah kepenuhan sehingga berdaya-guna dan berdaya menyejarah.

Poin ketiga dari tahapan ini adalah heuristika yang memberikan rambu-rambu dalam menyikapi dan menemukan sesuatu yang baru dalam suatu perubahan di bidang keilmuan. Kehidupan dengan segenap problematikanya selalu menyajikan dan menampilkan "wajah-wajah" yang berbeda dari waktu ke waktu, sehingga dalam konteks keilmuan suatu pengertian senantiasa terbuka untuk pengertian yang lainnya: kenyataan itu selalu lebih kaya dan lebih misterius daripada setiap teori (Bakker dan Zubair, 1990: 52). Heuristika dalam diskursus kefilsafatan merupakan sebuah aturan penalaran untuk penemuan (psikologis), dan tidak pembenaran (justifikasi). Heuristika merupakan suatu studi tentang perumusan logika penemuan yang di dalamnya pencarian difokuskan melalui suatu prosedur atau strategi tertentu untuk memberikan solusi terhadap suatu masalah (Iannone, 2001: 5).

Tahapan ini lebih ditekankan pada aspek subtilitas applicandi (theory of application), yang melalui ini dapat menunjukkan bahwa kegiatan memahami, mendeskripsikan dan menginterpretasikan pada akhirnya, akan menghadirkan suatu phronêsis atau pengetahuan praksis. Penerapan dari hal ini merupakan suatu situasi yang padu-padan dalam bingkai sebuah proyeksi atas makna teks yang membentang dalam horizon seorang penafsir. Tugas hermeneutika adalah untuk memberikan sebuah makna yang dapat digunakan (diterapkan) dari sebuah teks. Berangkat dari 'suatu tempat' kemudian seorang penafsir dibawa menuju cakrawala yang diperluas yang diperoleh melalui interaksi dialektis dan dialogis dengan sebuah teks (Gadamer, 2004: 310). Kondisi ini menjadikan penafsir dan yang ditafsirkan saling mengubah secara tidak sewenang-sewenang, memiliki nilai kepraktisan, dan merupakan cara agar kebenaran tersingkap (Smith, 1997: 27).

Aspek subtilitas applicandi ini, menurut Palmer (2005: 223), khususnya dalam sebuah interpretasi historis menjadi sesuatu yang relevan untuk digunakan, karena melalui ini pemahaman secara cepat dan sadar mengarah pada penerimaan makna 
teks dengan cara menjembatani jarak temporal yang telah memisahkan sang penafsir dari teks, dan dengan begitu, si penafsir mampu mengatasi alienasi makna yang telah menimpa teks. Kegiatan interpretasi berada dalam sinaran kekinian, tapi tidak berarti menguasai dan mendominasinya dengan kekinian tersebut, melainkan menerjemahkan makna klaim tersebut ke dalam suasana kekinian. Hermeneutik filosofis dengan demikian, merupakan suatu pergerakan restorasi makna, yaitu dengan hadirnya pemahaman baru terhadap suatu tradisi yang terbentang dalam sebuah teks.

\section{Wawasan dan Dinamika Budaya Melayu}

The Malays dan Malayness merupakan wacana yang muncul dalam rentang sejarah dan dinamika budaya Melayu, dan secara berterusan selalu menampilkan sisi-sisi yang mengetengahkan dua wacana yang dimaksud. Wacana ini, khususnya yang pertama, dalam dinamika dan khazanah budaya Melayu, kerap dieksplikasi dalam bentuk kategorial, seperti suku-bangsa (misal Hidayah, 1996: 177-182), atau di Malaysia pengertian Melayu masuk ke dalam ranah konstitutif, sebagaimana termaktub di dalam Undang-Undang Malaysia tentang Perlembagaan Persekutuan yang diperkenalkan pada saat hari kemerdekaan 31 Agustus 1957 yang menerangkan tentang definsi Melayu, yaitu "seseorang yang memeluk agama Islam, berbahasa dan beradat Melayu, serta keturunan dari orang yang lahir sebelum dan/atau saat hari merdeka Persekutuan Malaysia" (UndangUndang Malaysia: Perlembagaan Persekutuan, P.U (A) $164 / 2009)$.

Definisi konstitutif Melayu ini pada tahap lebih lanjut membedakan makna Melayu (misalnya) di tiga negara, Indonesia, Malaysia dan Singapura (lihat Wee, 1985: 7-8). Persoalan pemaknaan terhadap istilah Melayu ini sejak awal selalu memantik perbincangan serius di kalangan sarjana pemerhati khazanah budaya Melayu. Matheson (1979: 357-369) misalnya, dalam kajian terhadap beberapa naskah Melayu klasik (Sejarab Melayu, Hikayat Hang Tuah, Peringatan Sejarah Negeri Johor, Misa Melayu, Hikayat Patani, Hikayat Merong Mahawangsa, Tubfat al-Nafis, Kesab Pelayaran Abdullah dan Hikayat Abdullab) menemukan beragam arti dari nama atau istilah Melayu, ini semacam mengubah-suai dengan konteks yang ada. Konteks yang dimaksud itu misalnya tentang "asal mula penguasa" yaitu Bukit Si-Guntang, "asal-berasal" (tempat kelahiran nenek moyang), "orang Melayu," "anak Melayu," "hamba Melayu," "bangsa Melayu" (ras, garis keturunan), "bahasa Melayu," "adatistiadat Melayu," "nama Melayu," dan ada pula menyebut "tanah Melayu" dan "budaya Melayu."

Ragam arti yang terdapat di beberapa naskah di atas menunjukkan bahwa istilah Melayu tidak hanya diperuntukkan dalam suatu kondisi tertentu, tapi dihubungkan dengan banyak hal dan terkait berbagai peristiwa, serta kebutuhan untuk pelabelan atas suatu kedudukan. Kenyataan ini tentu tidak terlepas dari kepentingan khusus yang melatar-belakangi teks tersebut. Istilah Melayu, sebagaimana diungkapkan oleh Milner (2008: xi, 17; 2010), Being 'Malay,' ...means different things in different places, and at different times. ...It is not just a matter of their varying social and economic situations, and their differing degrees of political influence, but the whole concept of what it means to be 'Malay' can vary from one region to another.

Penelusuran terhadap naskah Sejarah Melayu (SM) khususnya, yang diterbitkan dalam beberapa versi atau edisi ditemukan bahwa pemakaian istilah Melayu dalam edisi Winsted (1938) digunakan sebanyak \pm 42 kali, edisi Shellabear (1967) sebanyak 49 kali, dan edisi Ahmad (2006) sebanyak 58 kali. Pemakaian istilah Melayu ini rata-rata dihubungkan dengan identitas (asal usul) orang atau tempat dan perihal adat-istiadat di lingkungan istana atau masyarakat (seperti larangan memakai pakaian warna kuning untuk orang lain atau orang biasa, penggunaan istilah patek untuk menyebut nama diri ketika menghadap raja, pakaian yang digunakan raja di saat pergi ke tempat ibadah, seorang hamba Melayu tidak akan [pernah] durhaka terhadap raja, aturan di dalam sebuah majelis, dan lain sebagainya).

Pemakaian dan pengorientasian dari istilah Melayu yang terangkum dalam naskah SM ini, oleh beberapa kalangan dinilai, bahwa cerita tentang silsilah dan adat-istiadat memberikan gambaran bahwa naskah ini ingin memberitahukan tentang kedaulatan dan kebesaran raja-raja Melayu, yang dengan itu diharapkan dapat melahirkan rasa takut dan diikuti kesetiaan kepada raja yang berkuasa (Fang, 2011: 442). Pada bagian lain juga dikatakan, bahwa naskah tersebut merupakan sebuah karya utuh dengan konsepsi politik pemerintahan yang satu dan mempunyai suatu komposisi yang bulat (Braginsky, 1998: 68) dengan memosisikan Melaka 
sebagai waris dari Sriwijaya (Wolters, 1990: 6; Andaya, 1997: 484). Sementara Abdullah (1989: 77) mencermatinya sebagai pembuktian akan hegemoni dinasti Palembang-Melaka-Johor, atau singkatnya, cerita tentang kebesaran Melaka yang memiliki kekuasaan yang luas.

Matheson (1979: 352) menyimpulkan, secara keseluruhan naskah SM mengandung beberapa informasi tentang kedudukan dan kebesaran kerajaan Melayu (Palembang-Melaka-Johor), yaitu (1) ingin menegaskan tentang garis keturunan penguasa Melaka-Johor yang secara langsung berasal dari Iskandar Zulkarnain yang berada di Bukit si-Guntang Melayu; (2) ingin menegaskan bahwa tradisi istana Melaka terus berlanjut sampai abad ke-17 di Johor, dan (3) bahwa Melaka pada zamannya merupakan kerajaan besar dan berjaya, serta hanya dapat disamakan dengan Pasai dan Majapahit.

Gambaran tentang pemakaian dan orientasi dari istilah Melayu, khususnya yang terdapat dalam naskah SM -yang oleh banyak kalangan kerap dirujuk untuk menelusuri sejarah Melayu- oleh Andaya (1997: 484) dikatakan sebagai "persepsi" orang Melayu terhadap masa lalu. Naskah ini kemudian dikemas dan disajikan dalam ragam ujaran yang sarat dengan aneka penafsiran dan penilaian. Pada poin ini, Teeuw (1952: x-xi; 1991: 122) memberikan penilaian, bahwa para penulis sastra Melayu tidak hanya melakukan tugasnya agak sembrono, tapi juga mendapat tugas dan bahkan kehormatan untuk memurnikan materi yang ditulis, menyederhanakannya sesuai dengan kondisi dan situasi, serta menghilangkan segala sesuatu yang dianggap tidak sejalan.

Penelusuran dan penelaahan terhadap persoalan ini jika diteruskan pada aspek kesejarahan, turut pula memantik sejumlah pandangan dari beberapa kalangan. Klaim Melaka sebagai pertuanan Melayu (pewaris Melayu Palembang, Sriwijaya) menimbulkan persoalan serius, terutama bila dikaitkan dengan bukti-bukti sejarah yang ditemukan. Penemuan berbagai bukti arkeologis dan prasasti, terutama sejak peralihan Sriwijaya Palembang ke kerajaan Melayu Jambi, dan kemudian pergeseran Melayu Jambi ke daerah 'pedalaman' (daratan tinggi [lihat Drakard, 1993: 36]) merupakan bagian dari sebuah sejarah keberadaan dan keberlanjutan kerajaan Melayu (Casparis, 1985: 245; Drakard, 1993: 23; Manguin, 1993: 29-31).
Pengalihan cerita dari Palembang ke Bintan dan terus Temasek yang dilakukan oleh para penulis silsilah raja-raja Melayu (teks SM dan Misa Melayu) dapat dipandang sebagai sebuah usaha untuk menutupi bagian sejarah pasca peralihan kekuasaan yang terjadi di abad ke-11, dari Sriwijaya Palembang (shib-li-fo-shib) ke Melayu Jambi (San-fo-ch'i) (Wolters, 1990: 65, 138, 204-205; Winstedt, 1935: 34-35). Pergeseran dari Palembang ke Melaka, oleh karenanya, merupakan rangkaian yang tanpa momentum signifikan dalam sejarah Melayu (Andaya dan Andaya, 1982: 34; Polo, Vol. II, 1903: 282 [n. 3]).

Kondisi di atas kemudian melahirkan sebuah upaya untuk memantapkan Melaka sebagai pusat dunia Melayu, dan ini menjadi sebuah pretensi yang tidak tertandingi oleh orang-orang di luar Melaka (Andaya, 2001: 328; Andaya dan Andaya, 1982: 36). Reid (2011: 24-26) mencatat, bahwa persoalan ini semakin menguat di saat kepentingan Inggris di Asia Tenggara berpindah dari Sumatra ke Malaya, sehingga segala sesuatu yang terkait dengan Melayu turut diambil alih oleh tetangga Sumatra.

Casparis (1985: 245) menyebutkan, penghubungan Melaka sebagai pewaris tradisi Sriwijaya lebih sulit untuk dipahami disebabkan keberadaan kerajaan Melayu yang sudah eksis di Sumatra Tengah melalui penemuan berbagai benda-benda bersejarah. Pencipta kerajaan Melayu yang baru sebagai pengganti Sriwijaya dan pendahulu dari negara Melayu yang berpusat di Melaka adalah Adityawarman yang merupakan penutup masa lama dan penerus dari tradisi "Hindu-Sumatra" (Casparis, 1992: 252; Coedes, 1975: 250).

'Keprihatinan' sejarah juga terungkap dalam kajian Kukushkin terhadap naskah Hikayat Negeri Jambi yang ditulis pada paruh kedua abad ke-19. Menurut Kukushkin (2004: 56), penulis naskah ini ingin memosisikan (sejarah) Jambi dalam sebuah ruang dan waktu. Jambi pada masa lalu pernah menjadi bagian penting dari sejarah (Melayu) Pulau Sumatra -bukan sebuah legenda belaka, di samping Melaka, Johor dan Mataram (Jawa). Relasi bulu-bilir yang pernah wujud pada masa lalu merupakan bagian dari sejarah yang pernah diperankan oleh Jambi sebagai basis awal kerajaan Melayu. Kondisi ini juga terungkap dari tulisan Zakaria, dkk. (Vol. II, 1989) yang berjudul Penelitian dan Pengkajian Naskah Kuno Daerah Jambi. Jambi oleh para pengkaji sejarah dipandang sebagai tempat yang 
penting karena sudah terjadinya peralihan kuasa (Wolters, 1966: 225-226). Wolters (1990: 5-6, $92-$ 95, 99-103; 1966: 233-234) dalam hal ini, sampai pada sebuah simpulan, bahwa anggapan yang menyebutkan Melaka sebagai pewaris Sriwijaya diragukan karena dua hal,

Pertama, pada abad ke-14 Sriwijaya hanya meninggalkan sisa-sisa dari nama besar sebuah kerajaan yang pernah berjaya, sehingga sangat tidak mungkin jika dikatakan Melaka (diperkirakan berdiri pada awal abad ke-15) dan Johor merupakan pewaris langsung dari Sriwijaya. Kedua, teks Sejarah Melayu yang memuat tentang asal usul raja dan kerajaan Melayu kerapkali kali dianggap sebagai cerita dongeng dan hanya sedikit memberikan fakta-fakta yang terkait dengan sejarah. Teks SM hanya dapat memberikan suatu gambaran umum tentang pemerintahan Melaka yang dipercayai sebagai pewaris Sriwijaya. Catatan Cina (Ming-shib) yang menerangkan tentang San-foch'i (Sriwijaya) dan sumber Jawa, serta beberapa dokumentasi perjalanan orang Portugis, seperti Tome Pires dapat dijadikan sebagai sumber yang lebih baik kalau ingin menelusuri sejarah awal kerajaan Melaka, sekalipun sumber-sumber asing tersebut tidak banyak menguraikan tentang pandangan orang Melayu terhadap peralihan dari Sumatra ke Semenanjung Tanah Melayu.

Pemilihan dan pemilahan atas bagian-bagian dari suatu sejarah akan menghadirkan implikasi tertentu dalam pembacaan suatu sejarah, terlebih jika dihubung-kaitkan dengan beberapa fenomena dan peristiwa budaya (adat dan tradisi) yang menapak dan menjejak dalam sejarah suatu budaya itu sendiri (wacana Malayness). Namun demikian, dalam konteks wacana The Malays, serangkaian catatan kritis yang dibentangkan di atas mungkin dapat diabaikan -ini tidak berarti menutup mata dari realitas sejarah yang ada- sebagai bentuk membangun kekuatan lokalitas, dan bahkan pada aspek politik misalnya, menjadi sebuah keniscayaan. Fakta menunjukkan, kuat dan lemahnya ideologi budaya internal merupakan faktor penting dalam memahami kekuatan politik tradisi yang dibangun (Kapferer, 1988: 211).

Kebutuhan akan aspek identitas lokalitas yang terbatas dan membatas (The Malays), sebagaimana yang dipermaklumkan dalam "piagam politik" provinsi Riau pada saat Hari Jadi yang ke-58 tahun 2015 sebagai kawasan Riau: The Homeland of Melayu misalnya, dapat dibaca sebagai sesuatu yang 'dibertentukan' untuk melokalisir sekelompok manusia ke dalam identitas bersama dalam suatu wilayah. Pembertentuan (pengkondisian) ini sebagai bentuk konstruksi komunitas yang dibutuhkan dalam sebuah kebijakan dengan dilandasi oleh pertimbangan tertentu (Ju Lan, dkk., 2010: 13-29). Boellstorff (2002: 25) menyebut pengkondisian ini sebagai ethnolocality (etnolokalitas) yang memberi penekanan pada skala spasial (kelompok etnis [suku] atau wilayah).

Kajian ini menyebut wacana The Malays sebagai bentuk sejarah dalam versi pendek, sementara Malayness merupakan sejarah dalam versi yang panjang. Pada aspek yang kedua inilah gagasan tentang penguatan nilai-nilai dan karakter keMelayu-an ingin ditumbuh-kembangkan, sehingga menjadi identitas Melayu tidak tersekat oleh ruang dan waktu (spatio-temporal), namun terhubung dan menjelma dalam ragam-bentuk praktek kehidupan. Wacana Malayness jauh lebih memberikan perspektif luas-mendalam bagi keberadaan dan keberlanjutan budaya Melayu jika dibandingkan dengan perbincangan di seputar The Malays yang cenderung berfokus pada isu etnisitas, genealogis dan politis (lihat Milner, 2008: xii, 17; Andaya, 2001: 316; Yusuf, 2009: 31).

Mengikut dengan pola sebaran budaya yang diketengahkan oleh Binford (1965: 204) dalam artikel yang berjudul Archaeological Systematics and the Study of Culture Process, bahwa budaya mengalir bagaikan arus dan kemudian membentuk variasivariasi kecil dalam norma ideasional. Variasi ini dalam kurun waktu tertentu "mengkristal" dan menghasilkan suatu klimaks budaya yang khas dan terkadang mencolok, sehingga dari sinilah dimungkinkan untuk membedakan kontinum budaya ke dalam fase-fase budaya yang ada. Arus budaya ini oleh Binford disebut dengan the aquatic view of culture.

Air yang mengalir ke segala arah, mengisi dan 'membasahi' ruang-ruang hidup, baik dalam skala yang besar ataupun kecil, sehingga membentuk pola budaya yang secara prinsip akan selalu berada dalam kerangka keterhubungan, tapi memiliki corak yang membedakan antar satu kelompok budaya dengan yang lain, seperti dalam sebuah ungkapan, "walaupun dalam adat yang sama, memakainya berbeda-beda" (Effendy, 2011: 1112). Asumsi budaya yang mengalir bagaikan arus ingin menjelaskan bahwa ayie diconcang ino putuib (air 
dicincang tidak putus) (Hamkaz, 2012: 36), dan dalam ungkapan lain juga dikatakan, Adat tak. lekang oleh panas, adat tak lapuk oleb hujan.

Pusaka yang tak dapat dirobah-robah, warisan yang tak putus oleh cencang.

kalau tinggi dipanjatnya,

Bila rendah dijalarnya.

(Effendy, 2005a: 117)

Penggambaran arus budaya yang demikian memberikan kesan bahwa suatu sejarah menapak dari kehidupan generasi ke generasi, memiliki matarantai yang menghubungkan dari satu masa ke masa berikutnya. Kontinuitas akan selalu mensyaratkan adanya unsur-unsur yang menghubungkan dan membentuk suatu kondisi, dan inilah yang disebut dengan unsur historis (Toynbee, 1947: 11), yang di dalamnya terdapat kelompok-kelompok masyarakat tertentu yang saling terpaut dan/atau mewariskan satu sama lain.

Gagasan yang melekat pada setiap unsur budaya hanya berfungsi sejauh membedakan, tapi tidak untuk memisahkan. Unsur budaya tidak ada dengan sendirinya dan tidak bisa dipahami tanpa hubungan dengan elemen lain (Fischer, 1946: 28). Kapferer (1988: 211) menyatakan, tidak ada tradisi yang dibangun atau diciptakan secara terputusputus atau terlepas dari suatu sejarah, dan tidak ada pula sesuatu yang keluar dari sebuah ruang hampa. Menemukan dan membaca sebuah sejarah sama artinya 'bertegur-sapa' dengan masa lalu yang di dalamnya mengandaikan kerendah-hatian dalam menyimak, atau bahkan menerima sesuatu yang mungkin bertentangan dengan pandangan semula yang sudah mewujud dalam kondisi ke-kini-an dan ke-di sini-an.

Sejalan dengan itu, dalam konteks kajian terhadap budaya Melayu (Riau khususnya), maka budaya Melayu tidaklah sepenuhnya merupakan budaya bahari (lihat Blagden, 1899: 212) sebagaimana yang banyak disinggung oleh sejumlah kalangan (misal Yusuf, 2009: 4-6; Junaidi, 2012: 15; Junaidi, dkk. 2013: 206, Hamidy, 2014: 8), tapi sekaligus pula mencakupi 'budaya daratan' (pedalaman, perbukitan) (lihat Kang, 2005: 21; Effendy, 2014: 6-7). Pencermatan terhadap pola budaya (adat dan tradisi) yang ada, baik yang menyangkut tentang sistem kepercayaan dan nilai, politik-pemerintahan, sistem mata-pencaharian, tradisi dalam bersastra, dan lain sebagainya, memberikan petunjuk tentang adanya keterhubungan antara 'budaya bahari' dan 'budaya daratan.' Perspektif Timur-Barat dan Utara-Selatan (lihat Kato, 1997: 752-755), atau bulu dan bilir barangkali dapat dijadikan sebagai alternatif berharga dalam mencermati setiap bagian dari keberadaan dan dinamika budaya Melayu secara luas (lihat Lapian 1992: 144-145; Andaya, 1993: 239-40; 1997: 484; Miksic, 1987: 23; Chou, 2006: 128-129; Wolters, 1979: 21; Kukushkin, 2004: 56; Kozok, 2006: 7-11). Perspektif bulu-bilir misalnya, merupakan suatu lingkungan yang menggambarkan ciri atau aspek kekhususan yang dapat memberikan informasi berharga untuk mencermati komposit budaya Melayu dan pemahaman tentang konfigurasi pengaruhnya (Kathirithamby-Wells, 1993: 92).

Arah kajian terhadap budaya Melayu (Malayness) dalam konteks penyelisikan dan pencermatan terhadap nilai-nilai khazanah budaya Melayu secara mendasar tentu harus diarahkan dalam perspektif ini. Hal ini tidak saja dibutuhkan sebagai pelacakan dari nilai-nilai asas, tapi sekaligus pula dalam upaya untuk memberikan muatan filosofis di tengah 'pergelutan' ide-ide besar dunia dan dalam rangka penguatan karakter manusia Melayu yang didasarkan pada aspek budaya. Pendekatan kefilsafatan (hermeneutika filosofis) dalam hal ini, akan memberikan ruang bagi suatu kebudayaan untuk melakukan interaksi dan dialog dengan sesama manusia dan kebudayaan lainnya (Peursen, 2003: 7). Penekanan pada aspek karakter dalam mencermati dinamika dan fenomena suatu budaya sejalan dengan ulasan Espagne (2014: 114-116) tentang bagaimana peradaban Yunani ditransformasikan melalui ragam usaha, yang kemudian menstimulus dan membentuk suatu kondisi (tradisi filsafat Jerman) yang hari ini dikenal dengan Bildung.

Konsep Bildung merupakan suatu proses dialog yang dilakukan secara terus menerus dan bersifat formatif dan transformatif (proses menjadi) (Hardiman, 2015: 195-196). Davey (2006: 37-40) menjelaskan, bahwa proses transformatif dihasilkan dari pemahaman hermeneutik dalam pendalaman pengalaman hermeneutik, dan membentuk (dalam pengertian formatif) sesuatu menjadi ada. Konsep Bildung oleh karenanya, ingin menunjukkan bahwa di samping pengetahuan ilmiah dan teknis, terdapat suatu bagian lain dari pengetahuan yang bukan merupakan hasil dari pembuktian dan demonstrasi, namun diterima 
sebagai sebuah kebijaksanaan dan pengalaman praktis (phronesis), dan itu ditetapkan oleh tradisi. Tradisi, sebagaimana dijelaskan oleh Lawn dan Keane (2011: 141) bukanlah sesuatu yang mengandung pemikiran yang tidak reflektif, yang mengaburkan dan mendistorsi pemikiran masa kini, melainkan sebenarnya membuat suatu pemikiran (pemahaman) menjadi hadir di tengah kehidupan hari ini. Di sini, tradisi yang mendasari atau memungkinkan 'rasa-menjadi-bagian' (Gusmao, 2012: 105) yang dilakukan melalui perjumpaan dan proses dialektis antar horizon yang membentang, kemudian melebur dan menyatu pada struktur pemahaman eksistensial (Lawn and Keane, 2011: 77). Pada titik ini, maka proses memahami (Verstehen) "selalu merupakan peleburan borizon-horizon yang dianggap ada dengan sendirinya, ...proyeksi horizon merupakan sebuah fase di dalam proses pemahaman yang tidak membeku ke dalam alienasi diri, melainkan diambil alib oleh horizon pemahaman masa kini dari seorang penafsir" (Gadamer, 2004: 305).

Pemahaman yang demikian, dengan menggunakan alur hermeneutik akan memberikan sebuah landasan etik (lihat Davey, 2006: 42; Veith, 2015: 148) yang tidak tereduksi ke dalam makna yang an sich bersifat emik. Kedua bentuk istilah ini (etik dan emik) sekalipun dalam kajian antopologis merupakan definisi yang berkait dengan dasar dan konstruksi epistemologis yang digunakan dalam mencermati dan mengikhtisar suatu fenomena budaya (lihat Harris 1976: 331; Lett, 1990: 130131), tapi menurut Miksic (1987: 35), definisi yang bersifat emik cenderung mendevaluasi Melayu dari sisi budaya.

Melayu sebagai sebuah terminologi dan sekaligus wacana tentang ke-Melayu-an (Malayness) dalam sejarahnya selalu mengetengahkan perjumpaan dengan berbagai peradaban besar dunia. Perjumpaan itu tidak jarang diliputi oleh suasana yang sarat dengan muatan emosi dan gagasan, dan kadang diinsafi sebagai sesuatu 'mendewasakan' untuk suatu identitas yang berkekalan. Perjumpaan tentu membawa dinamisasi bagi kehidupan secara luas-mendalam, terutama yang menyangkut dengan pendasaran yang bercorak 'ideologis.' Pada titik ini, ke-Melayu-an tidak dapat dimaknai sebagai sebuah entitas yang terpisah dan berdiri sendiri, serta tertutup dan terlepas dari mata-rantai yang menghubungkan identitas ke-Melayu-an lainnya. Ke-Melayu-an tidak pula an sich menyandarkan pada era kejayaan kerajaan tertentu, misalnya
Melaka, melainkan ditempatkan dalam sebuah bingkai sejarah yang saling memengaruhi dan/atau dipengaruhi, sebagai terekam dalam beberapa situasi dan peristiwa penting yang akan diterangkan di bawah.

\section{Pendasaran dan Sistem Nilai Budaya Melayu}

Budaya Melayu, sebagaimana jamak diketahui terbentuk dari rangkaian sejarah panjang, yang secara umum mengakar pada dua peradaban besar, yaitu di satu sisi animisme-dinamisme dan HinduBudha, dan pada sisi lain Islam sebagai sistem keyakinan baru (pola kepercayaan lama dan pola kepercayaan baru). Dua peradaban ini secara nyata menyisakan sejumlah bekas, dan bahkan membertentukan budaya Melayu, serta memberikan corak yang berbeda dari budaya lainnya.

Peralihan dari sistem kepercayaan yang berbasis pada budaya kepada keyakinan yang disandarkan pada suatu agama, atau dari sistem keagamaan lokal kepada sistem keagamaan Islam dalam kehidupan masyarakat Melayu tidaklah berjalan secara frontal, dalam pengertian saling berhadap-hadapan antara kepercayaan lama di satu sisi dengan keyakinan pada agama tertentu pada sisi yang lain (Hamidy, 1999a: 14). Kedudukan kepercayaan lama masih diakomodir sebagai varian yang menandakan adanya jejak-jejak pengaruh kepercayaan lama (alHelmy, 1963: 23-24). Pandangan dan pemahaman yang bercorak Hinduisme atau kepercayaan lama merupakan nilai dan tradisi yang pertama kali dikenal dan bersentuhan dengan kehidupan masyarakat Melayu dan dirasakan lebih dekat dengan berbagai suasana, sehingga tidak sedikit dari praktek-praktek kehidupan masih diwarnai oleh ajaran-ajaran atau nilai yang berasal dari pra-Islam (Alam, 1920: 4-6; Hamidy, 1999b: 42-43). Pengaruh itu bahkan sudah berlangsung sejak abad ke-1 sampai sekitar abad ke-12 (Osman, 1988: 151).

Dialektika agama dan budaya lokal merupakan sebuah realitas yang hampir-hampir tidak bisa dipisahkan dalam rentang kehidupan masyarakat Melayu. Islam sebagai agama 'penutup' yang bersentuhan dan memberikan pengaruh tidak serta merta dapat mengubah dinamika kehidupan masyarakat secarah utuh-menyeluruh (Umar, dkk., 1977: 96). Kepercayaan lama yang masih dijadikan sebagai 'pedoman' -sekalipun tidak lagi dalam bentuk aslinya, namun sampai hari ini masih dimungkinkan untuk menelusuri jejak-jejak kepercayaan tersebut melalui sejumlah praktek 
kehidupan yang berlangsung dari waktu ke waktu (Yusuf, 2009: 35-53).

Kepercayaan lama merupakan suatu bagian dari sistem kepercayaan orang Melayu, di samping adanya bentuk-bentuk penghormatan terhadap unsur-unsur Islam yang umum dalam kehidupan sehari-hari (Osman, 1989: 95). Alih-alih dikatakan sebagai penganut kepercayaan lama, orang Melayu justru menyebut "menjadi Melayu, berarti menjadi Islam," sekalipun tidak mengamalkan ajaran Islam secara utuh dan sempurna (Marsden, 1811: 42; Swettenham, 1895: 4-5).

Peralihan sistem kepercayaan lama ke dalam bentuk keyakinan agama menyiratkan dua kondisi yang memiliki kontribusi bagi masyarakat secara luas, khususnya di lingkungan masyarakat Melayu. Dua kondisi ini merupakan detail yang berkelindan dalam keseluruhan rangkaian sejarah yang pernah bermukim dan bersinggungan dengan kehidupan masyarakat yang berada di kawasan Kepulauan Melayu-Indonesia.

Persinggungan itu meninggalkan sejumlah rekam-jejak yang harus diakui masih dikelola-bina sebagai bagian dari tradisi leluhur, seperti tradisi dalam berkesenian. Rahman, dkk., (2010: 14) menyebut, berbagai corak dan jenis seni (misal syair, hikayat, legenda, nyanyian rakyat, dan lainnya) merupakan inti lingkaran dari setiap unsur kebudayaan yang berhubung-kait dengan sistem religius (kepercayaan). Oleh sebab itu, dalam konteks inilah perbincangan tentang sistem kepercayaan orang Melayu tidak akan lengkap bila hanya menjelaskan agama (Islam) resmi yang dianut, tanpa menyinggung kepercayaan lama sebagai warisan leluhur, ungkap Hasbullah, dkk (2014: 22).

Gambaran tentang dua kondisi yang dimaksud di atas, pada gilirannya dapat dilihat sebagai, pertama, kepercayaan lama yang berkembang dan terbentuk menjadi suatu budaya atau adat kebiasaan semakin menguatkan pandangan bahwa kedudukan dan peran penting manusia dalam kehidupan tidak saja menyangkut masalah kedirian (individu), melainkan bagaimana turut serta dan secara bersama-sama dengan 'yang-lain' memperkembangkan kehidupan dalam pengertiannya yang luas.

Kedua, perjumpaan kepercayaan lama dengan sistem keyakinan baru (agama) tidak saling menegasikan, melainkan bersifat menapis dan kadang terkesan reposisi dari adat dan tradisi yang masih didominasi oleh kepercayaan lama ke pemahaman yang dilandaskan pada Islam, dan dengan itu menempatkan Islam sebagai landasan berpijak dan menjadi rujukan utama dalam praktek kehidupan masyarakat. Pada bagian lain, budaya atau adat kebiasaan berada pada lapisan di bawah, yang salah satu fungsinya adalah mengikat dan mempersatukan berbagai latar belakang agama, suku atau etnis yang ada, khususnya yang datang dan berdomisili di kawasan Kepulauan MelayuIndonesia (Hamidy, 1996: 39): di mana bumi dipijak, di situ langit dijunjung. Adat atau tradisi menjadi jalan tengah jika dalam haluan keberagamaan berbeda, namun direkat oleh oleh nilai-nilai ke-Melayu-an yang lain, yaitu budaya dan bahasa (Effendy, 2005b: 34).

Perjumpaan agama (Islam) dengan adat yang bersumber pada pola kepercayaan lama yang disinggung pada poin dua di atas lebih dimaknai sebagai saling 'berebut pengaruh,' di mana Islam menggeser dan bertukar tempat dengan pola kepercayaan lama, untuk kemudian muncul sebagai identitas baru, "Melayu itu Islam." Proses peralihan ini, oleh Effendy (2005b: 32; 2013: 6) kerap disebut dengan penapisan (eklektik), atau Hamidy (1998: 45; 1996: 38-39) menyebutnya dengan diubah-suai. Adapun Mutalib (1990: 13) menyebut fenomena ini sebagai doktrin Islam bastar (hybrid) dan beraneka ragam, yang terdiri dari unsur praktek-praktek Islam maupun non-Islam yang diserap ke dalam lingkungan masyarakat Melayu.

Kajian ini menyoroti bahwa fenomena yang terjadi dalam peristiwa perjumpaan dua peradaban besar merupakan suatu peristiwa "pemuncakan budaya" ke kondisi yang lebih bersesuaian dengan segala bentuk perwujudan 'kepentingan' manusia dalam kehidupan keduniaan-kesemestaan. "Pemuncakan" ini jika mengikut alur pikir hermeneutika filosofis Gadamer, bukanlah suatu penemuan atau pemilikan bagi terbentuknya suatu pemahaman, melainkan pemadatan cakrawala yang lebur dan lumer dalam citra yang baru dan membentuk sebuah horizon yang lebih besar, yang di situ kehidupan manusia berasal dan diturunkan (Gusmao, 2012: 114; Lawn dan Keane, 2011: 152). Horizon-horizon itu mempertemukan dan saling member-arti-kan dan member-nilai-kan satu sama lain.

"Pemuncakan budaya" inilah yang dalam kajian ini disebut dengan fresh culture, suatu kondisi dan peristiwa penguat-kukuhan yang tercermin dari 
perubahan paradigma (maksim adat: Adat bersendi Syarak, Syarak bersendi Kitabullah= ABS-SBK) dan praktek budaya, dari pola kepercayaan lama ke sistem keyakinan baru, yaitu Islam. Budaya tumbuh menjadi suatu kekuatan baru, baik sebagai identitas ke-diri-an (jati diri) maupun perekat masyarakat di kawasan Kepulauan Melayu-Indonesia, atau jamak disebut dengan bangsa Melayu serumpun. Perjumpaan memberikan suasana baru bagi dinamika kehidupan yang di dalamnya memuat sejumlah penggambaran dan pijakan yang dapat dirujuk ke dalam bagian-bagian tertentu dari suatu sejarah. Kondisi ini sejalan dengan keterangan Gadamer (2004: 301), bahwa setiap situasi menyediakan peluang bagi pribadi untuk mengindra dan mendapati dirinya, serta memberikan sinaran cahaya di atasnya.

Fresh culture sebagai sebuah fenomena budaya tidak saja mengetengahkan peristiwa penguatkukuhan dan "pemuncakan budaya" yang kemudian dijadikan sebagai pendasaran dan peneguhan atas identitas, tapi secara prinsip membertentukan budaya Melayu dalam arus besar Islamisasi peradaban. Pemakluman bahwa Melayu itu Islam dapat dipandang sebagai pelabelan budaya Melayu yang bercorak ideologis (teologis), sehingga eksistensi dan identitas ke-Melayu-an menampilkan bentuk ideal yang berbeda secara signifikan dari masa sebelumnya. Peristiwa ini sesungguhnya merupakan bagian dari upaya mendalilkan (argumen) secara ontologis untuk suatu dinamisasi per-gerak-an budaya dan enkulturasi.

Peralihan sistem tulisan dari Sanskerta ke Jawi (Arab Melayu) (lihat Chambert-Loir, 2009: 185189; Braginsky, 1998: 93), penambatan maksim adat (ABS-SBK), pengolongan dan penempatan adat secara hierarkis (adat sebenar adat [Islam], adat yang diadatkan [adat], dan adat yang teradat [tradisi]) merupakan di antara rangkaian dari peristiwa budaya yang sarat dengan nilai yang di dalamnya memuat sejumlah gagasan yang berpadu dengan unsur emosional untuk menghasilkan pola dan laku budaya yang distingtif (cipta, rasa, karsa), terlebih jika ditelaah lebih lanjut dan dihubungkaitkan dengan penggunaan beberapa terminologi penting dalam budaya Melayu, seperti resam, 'azam, dan adat -yang ketiga istilah ini notabene diserap dari bahasa Arab. Poin-poin inilah yang secara diskursif dapat dicermati (dan ditelaah lebih lanjut) sebagai bentuk penguatan lain dari budaya
Melayu, khususnya dari sisi epistemologis dan aksiologis.

Di samping beberapa peristiwa di atas, "pemuncakan budaya" juga terekam melalui pemaknaan baru terhadap istilah Melayu, sebagaimana termaktub di dalam naskah Adat Raja-Raja Melayu yang disusun pada tahun $1193 \mathrm{H}$ (1779 M) atas perintah De Bruyn, pejabat Gubernur Melaka (Fang, 2011: 551-552). Naskah ini memberikan tafsiran baru terhadap pengertian Melayu, yaitu dimaknai sebagai,

"me-melayu-kan diri," ibarat sebatang pohon yang memiliki cabang dan ranting, yang dari situ tumbuh dedaunan dan kemudian merunduk (layu). Daun yang merunduk itu bukan disebabkan oleh terkena sinar matahari atau terbakar oleh api, melainkan dimaknai dengan sikap dan perilaku yang bersahaja, merendahkan diri, dan bukan sebaliknya, tidak mau membesarkan diri. Sikap dan perilaku yang demikian tercermin dari adab dan tata-tertib serta bahasa, baik yang berkedudukan atau tidak, dan ini berlaku di dalam suatu majelis maupun di luar majelis. Melayu juga bermakna sebagai suatu kondisi 'tengahan' dalam setiap perkataan, berpakaian, perkara makan dan minum, tidak menonjolkan diri merupakan sikap dan perilaku yang disebut dengan "anak yang majelis" (Sudjiman, 1983: 142-143).

Pemaknaan yang berbeda dari kata yang sama di atas diungkapkan pula oleh Taslim dan Junaidi (Jilid 2: 2007: 579), bahwa kata malai (malay) diartikan sebagai tumbuhan yang layu karena kurang air, atau terkena teriknya sinar matahari. Makna ini dipandang sebagai kata kiasan yang melambangkan bahwa orang Melayu itu aluih (halus), bòradab (beradab), bòradat (beradat), bòtimbang rasò (saling pengertian), halus dalam permainan akal dan pada saat tertentu pandai pula bertutur kata halus (Junaidi, dkk., 2013: 191).

Fenomena yang terekam dalam beberapa peristiwa di atas tidak lain adalah merupakan sebuah proses peralihan ideologis ke ideologi yang diwujudkan dalam bentuk pembangunan dan penata-laksanaan suatu ideologi baru (Furniss, 2004: 118; Errington, 2000: 15-17), yaitu Islam sebagai sebuah pendasaran budaya. Pencanangan Islam sebagai ideologi baru secara berangsur dan berjenjang memberikan pengaruh dan membina suatu pola pikir dan pemahaman baru, dan seterusnya berimplikasi pada kegiatan-kegiatan 
yang berada dalam dimensi ruang dan waktu, baik yang berhubungan dengan praktek-praktek kehidupan di tengah masyarakat maupun yang disifati sebagai peristiwa adat atau tradisi yang berlaku di lingkungan istana.

Masuk dan berkembangnya Islam di Kepulauan Melayu-Indonesia yang diikuti dengan wujud-laku pembudayaan, dengan demikian memberikan pengaruh dalam taraf maksimum, sementara adat dan tradisi yang bersumber pada pola kepercayaan lama tetap menjadi bagian yang tidak terpisahkan dari kehidupan masyarakat Melayu, dan berada pada taraf minimum. Taraf maksimum dan minimum ini akan terlihat dengan jelas melalui sistem nilai yang dianut dan berlaku di lingkungan masyarakat Melayu dan dibedakan menjadi tiga dasar atau sumber, yaitu Islam, adat dan tradisi (lihat Hamidy, 1999a: 16, 96-97; 2014: 52). Sistem nilai ini dalam konteks hukum adat tidak sedikit diserap dan dijadikan sebagai sumber dalam pembentukan maupun pelaksanaan hukum adat itu sendiri (lihat Effendy, 2005a: xiii; Suwardi, dkk., 2011: 20).

Poin penting dalam permakluman sistem nilai ini adalah bahwa ketiga sistem nilai tidak bersifat hitam-putih, melainkan ketiga sistem nilai diberikan ruang sebagaimana mestinya tanpa harus saling meniadakan (menegasikan) satu sama lain. Pada tempat dan momen-momen tertentu, kedudukan ketiga sistem nilai kadang ditentukan dari tingkat keterpengaruhan dan penerimaan masyarakat terhadap sistem yang ada. Kondisi ini dapat dipersaksikan misalnya dalam praktek kehidupan di lingkungan masyarakat urban dengan yang berada di perdesaan atau perkampungan yang jauh dari suasana keramaian.

Pembagian dan penetapan adat yang demikian, jika digambarkan seperti bentuk piramida terbalik (bersifat top-down). Agama pada level yang tertinggi berfungsi di samping sebagai dasar, juga memberikan peng-arah-an terhadap dua sistem nilai yang lain. Ajaran dan nilai-nilai yang bersumber dari agama bersifat mutlak dan tidak bisa digantikan dengan yang lain, sementara dua sistem nilai yang lain bersifat relatif.

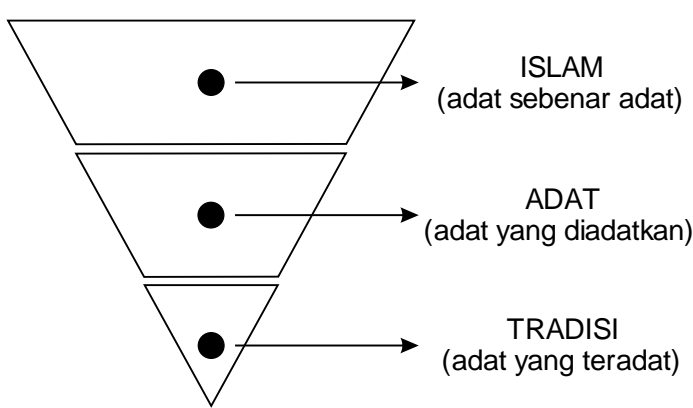

Gambar 1

Sistem dan Hierarki Nilai Masyarakat Melayu

Penggolongan dan penempatan adat ini merupakan cara orang Melayu dalam menyikapi dan menempatkan sesuatu pada posisinya, yang disesuaikan dengan kualitas dari setiap sistem nilai yang ada. Penggolongan ini sebagai lanjutan dan petanda mulai bersebatinya budaya Melayu dengan Islam, dan sekaligus mengetengahkan sebuah fakta sejarah bahwa adat dan tradisi 'menempel' dan menjadi bagian dari budaya Melayu. Pembagian adat menjadi tiga bagian membedakan secara distingtif dan sekaligus membuat sistem nilai adat menjadi bersifat hierarkis.

\section{"Hati-Budi" Melayu sebagai Locus Pengetahuan}

"Hati" merupakan tema perennial yang muncul di sepanjang waktu dan di seluruh bagian kehidupan (misal agama, budaya). Tema ini kadang dikontraskan dengan tema lain seperti rasionalitas, dan bahkan dalam diskursus tertentu saling menegasikan, sehingga memunculkan pandangan tentang perbedaan antar Timur dan Barat. Pandangan inipun secara serius memantik anggapan bahwa "hati" kerap dihubung-kaitkan sebagai sumber subjektivitas, dan sebaliknya, rasionalitas sebagai ciri dan indikasi dari adanya objektivitas.

Perbincangan tentang persoalan ini dalam konteks khazanah budaya Melayu berbeda dengan apa yang disinggung di atas, karena tema "hati" lebih cenderung dikaitkan dengan alur dan alir tradisi yang terdapat dalam khazanah peradaban Islam, seperti yang diulas al-Ghazali (1910: 19-25, 34-35) dalam kitab yang berjudul Kìmiyā' alSa'ādah (The Alchemy of Happiness). Pandangan ini sejalan pula dengan anggapan bahwa corak Islam yang berkembang di Kepulauan MelayuIndonesia bersumber dari pandangan dan ajaran 
tasawuf (lihat al-Attas, 1990: 37, 71; Braginsky, 1993; Hadi, 2008: 137).

Daya kognitif dan keaktifan "hati" memengaruhi banyak aspek dalam kehidupan masyarakat Melayu (terutama di bidang sastra) dan tidak sedikit dijadikan sebagai orientasi dalam meng-gerak-an dinamika budaya Melayu secara luas-mendalam. Menurut Braginsky (1998: 169), dalam karya-karya puisi Melayu istilah hati nurani ("kalbu rohani") biasanya digunakan sebagai asas untuk merenungi dunia noumenal dan menerima inspirasi dari sana. Sementara akal biasanya lebih banyak disebut dalam melukiskan 'tahap agentif penciptaan, artinya tahap penentuan ide/citra dalam bentuk tertulis, daripada dalam melukiskan 'tahap reseptif.' Akal dengan demikian menjalankan fungsi pengaturan dalam dinyatakannya verbal tentang sesuatu kesan yang ditangkap oleh hati nurani.

Pada konteks ini, mendekati dan menelusuri dinamika manusia dalam ranah budaya Melayu berarti menyelami "hati" orang Melayu dalam serangkaian peristiwa kehidupan. Raja Ali Haji (2002: 6) dalam salah satu bait Gurindamnya menyebut, hati itu kerajaan di dalam tubuh, jikalau zalim segala anggotapun roboh, atau dalam ungkapan lain dikatakan, hati lebam dunia karam, hati berbulu tak beraib malu (Effendy, 2010: 331332). Goddard (2001: 167-168, 170, 176) yang tulisan berjudul Hati: A Key Word in the Malay Vocabulary of Emotion menjelaskan, bahwa "hati" merupakan salah satu key words dari kebudayaan Melayu (ethnopsychological terms) dan berfungsi sebagai titik fokus konseptual untuk seluruh kompleks nilai, sikap dan harapan yang khas Melayu. Kata ini tidak identik secara semantik dengan heart (Inggris), karena "hati" orang Melayu lebih menekankan aspek kognitif dan lebih aktif. Oleh karenanya dikatakan, bahwa "hati" adalah alam, inner realm, orang lain tidak dapat mengetahui isi hati seseorang kecuali diluahkan oleh orang yang bersangkutan. Lim (2003: 90) menambahkan, bahwa kristalisasi tertinggi dari pikiran orang Melayu adalah menggabungkan antara pikiran dan perasaan (misal peribahasa).

Konsepsi "hati" yang digambarkan oleh Goddard di atas, sejalan dengan penempatan persoalan "hati" sebagai tema sentral dalam diskursus etika. Kata "hati" dalam etika kerap disandingkan dengan istilah lain, yaitu "nurani?" yang bermakna suatu sinar (cahaya), atau sesuatu yang berasal dari bagian terdalam pada tubuh manusia (lubuk hati). Menurut Bertens (1994: 5153), hati merupakan wadah bagi penghayatan tentang perkara-perkara yang baik atau buruk, dan ini berhubungan dengan tingkah laku konkrit (tidak berlaku umum): perintah atau larangan. "Hati" merupakan tempat 'persaksian' tentang perbuatan yang berhubungan dengan moral, sehingga tidak heran dalam bahasa Latin disebut conscientia. 'Persaksian' ini bermakna bahwa yang dituntut untuk sebuah pertanggungjawaban tidak lain adalah hati (Shihab, 2007: 382).

"Hati" menjadikan manusia sebagai makhluk yang berkesadaran atas apa yang ada pada diri dan lingkungan, dan melalui itu tumbuh sikap penjagaan (kewaspadaan). Menutup nurani "hati" berarti maniadakan ruang kesadaran untuk bekerja secara tertuntun. "Hati" disebut sebagai salah satu lembaga normatif yang ada dalam kehidupan (Magnis-Suseno, 1987: 49-50), dan oleh karenanya, tidak mengikuti "hati" sama artinya menghancurkan integritas pribadi dan mengkhianati martabat terdalam (Bertens, 1994: 52), dan ini meruntuhkan nilai sebagai seorang manusia (Magnis-Suseno, 1987: 54).

Istilah "hati" jika dilihat dalam kamus Bahasa Indonesia merupakan suatu unsur yang terdapat pada manusia dan dianggap sebagai tempat segala perasaan batin yang memuat pengertian-pengertian (Pusat Bahasa, 2008: 514), atau biasanya disandingkan dengan kata batin, jiwa, gaib (Ikram, dkk., 1985: 90). Menurut Musa (2008: 6), dalam bahasa Melayu, "hati" merupakan unsur yang halus dan bersifat rohaniah yang berkemampuan untuk menyadari (perasaan dan keinginan) segala sesuatu yang diketahui, dalam bentuk perintah atau larangan. Lim (2003: 164) mengatakan, bagi orang Melayu "hati" tidak hanya sebagai sumber dan pusat emosi, tapi juga merupakan pusat kehidupan, semangat ('roh'), nafsu, intuisi dan jiwa.

"Hati" sebagai sebuah istilah yang lazim digunakan dalam praksisnya memiliki beberapa bentuk derivatif, di antaranya (dalam bentuk adjektif) sebagai "pengindraan" (cermat, seksama; hati-hati, teliti), "daya tangkap" (tulus, silap hati), "kepekaan" (murah hati, humanistis), "kebenaran" (lurus hati), "kecewa" atau "marah" (kecil hati, merajuk), "cemburu" (iri hati, dendam), "putus asa" (semak hati), "baik" (baik hati), "komunikasi" (baik hati), "moral" atau "nilai" (murah hati), dan 
lain sebagainya (Tesaurus Tematis Bahasa Indonesia, sumber: daring).

Pencermatan terhadap pengertian dan beberapa sifat yang dilekatkan pada istilah "hati" di atas, dalam kajian ini diikhtisar menjadi dua kondisi, yaitu "hati aktif" dan "hati pasif." Kondisi pertama cenderung dipengaruhi oleh unsur perasaan, sehingga di saat dikaitkan dengan kata "pasif," maka dapat dimengerti sebagai suatu kondisi statis, bertahan, mundur, atau kadang memuncak, berontak (Hamidy, 1996: 28-31). Kondisi ini ditampilkan dari sejumlah sikap dan sifat yang kerapkali dihubungkan dengan kehidupan masyarakat Melayu, seperti sifat malu, menghindar dan merajuk, latah dan aruk, dan berakhir dengan amuk (lihat Hamidy, 1986: 23-24; 1996: 28-32; 2014: 15-17; Rab, 2007: 464; Kadir, 2007: 484-486).

Adapun "hati aktif' lebih ke arah pengertian generik yang mengaktifkan daya rasa dan nalar. "Aktif" di sini tidak dimengerti sebagai suatu kondisi yang tidak senonoh, frontal, sewenangwenang, kesat, dan seterusnya, melainkan sebaliknya, ber-alur dan ber-patut-an: santun atau halus, kepekaan, kehati-hatian (menghematcermat), dan yang lain. Pengertian ini lebih dekat maknanya ke an-nafs an-nātiqah (jiwa yang berpikir), atau dalam konteks kajian ini disebut dengan istilah "budi." Istilah ini, jika merujuk ke dalam kamus Sanskerta berakar dari kata buddhi yang memiliki makna di antaranya (1) kekuatan untuk membentuk dan mempertahankan gagasan dan pengertian (kecerdasan, kearifan, penuh pertimbangan), (2) daya paham (tangkap) atau kemengertian, dan (3) pengetahuan mengenai diri (psikologi) (Monier-William, 1956: 733).

Dua kondisi "hati" di atas (aktif dan pasif) tidak harus diperlawankan karena keduanya memuat makna dan berfungsi dalam meng-gerak-an manusia secara utuh-menyeluruh, mendinamisasi kehidupan dalam kerangka "hati-budi" Melayu. "Hati" dalam pengertiannya sebagai perasaan tidak selalu menunjuk pada kondisi negatif, subjektif, pasif, dan seterusnya, melainkan dapat mencuatkan suatu kemampuan dalam me-rasa, dan ini sungguh menjadi peristiwa yang terang di hampir setiap budaya masyarakat (lihat Zoetmulder, 1991: 189, 216-218; Magnis-Suseno, 2003: 130-131; Nasroen, 1957: 172; Lim, 2003: 90, 164; Musa, 2008: 6). Rasa akan menghadirkan sikap yang lurus dan tidak bengkok, terang (jujur) dan tidak disamarkan (hipokrit). Rasa merupakan daerah istimewa manusia (Supadjar, 1993: 125), karena kerap kali hanya rasa yang bisa memahami alasan-alasan yang tidak dimengerti oleh akal (Driyarkara, 2006: 21).

"Hati" mempertautkan sesuatu yang jauh dan berjarak (dalam dan lintas ruang-waktu), sehingga kehidupan bisa dirasakan dan diresapi dalam bingkai harmoni untuk suatu penguat-kukuhan. "Budi" menjernihkan segala sesuatu yang ditutupi atau dikaburkan oleh hasrat keduniaan yang mewujud dalam bentuk kebendaan, sehingga berpotensi merusak tata-hubung dan keharmonian. Kondisi ber-hati-budi berarti berhati dan berakal budi yang merangkum dua keutamaan dan mewujud-laku dalam kepribadian yang tercerahkan sekaligus terselamatkan secara batin dan lahir. Perspektif ini ingin menegaskan dan menunjukkan bahwa berpikir (pemikiran) belum sepenuhnya memberikan jaminan terhadap kebaikan manusia (Driyarkara, 2006: 100), melainkan dibutuhkan kemampuan ber-rasa (hati) untuk mengenal dan merasa berbagai entitas dan peristiwa yang ada.

Sampai di sini, "Hati-budi" dalam khazanah budaya Melayu merupakan asas dan locus pengetahuan, sehingga secara dominan memengaruhi corak budaya Melayu, utamanya yang tersebar di berbagai karya-karya di bidang sastra, seperti pantun, peribahasa, mantra, dan lain sebagainya, maupun melalui rekam-jejak adat dan tradisi masyarakat. Adat dalam bentuknya sebagai ujaran-ujaran (tradisi lisan) yang sarat dengan identitas lokalitas juga berfungsi dalam menerangjelaskan ke khalayak akan relung-relung hikmah yang samar dari mata penglihatan jasmaniah, untuk kemudian menghadirkan ketajaman dan kejernihan "hati-budi": di dalam membina manusia, akal-budi jadi tiangnya (Effendy, 2005b: 113); arif menyimak kicau burung, bijak menengok musim beralih, pandai membilang bintang di langit, cerdik menghitung muka belakang (Effendy, 1986a: 16). Ketajaman dan kejernihan ini diibaratkan oleh Wilkinson (1932: 72) sebagai is the Lamp of the Mind; calm reflection is the Heaven of the intelligent; a bull's eye of wisdom is not to be scored at the first shot. Hadot (1995: 58-59) menyebutnya sebagai kebijaksanaan yang memuat suatu visi tentang alam semesta dalam terang akal yang membentuk suatu keadaan yang ideal sehingga menjadi anutan dan bagian dari cara hidup. 
"Hati-budi" dengan demikian, menjadi cakrawala dalam membukakan jalan dan ruang, untuk kemudian menuntun ke arah yang ber-alur dan ber-patut-an. "Hati-budi" memiliki sensitivitas terhadap perkara-perkara yang ada di sekitar, sehingga tidak berlebihan jika dikatakan bahwa "hati-budi" acapkali memberikan orientasi dalam setiap wujud-laku, baik terhadap Tuhan sebagai pemilik dan penguasa kehidupan, maupun dalam berinteraksi dengan orang-orang di sekitar. Hidup manusia tidak semata menyangkut soal cara berpikir tentang kehidupan, melainkan pula bagaimana merasakan hidup itu sendiri, ungap Schwartz dan Russek (1998: ix).

Adapun segala yang budiman itu,

apabila ia melihat yang zahir,

maka diketahui-nyalah yang batin.

(Wilkinson, Part 1, 1901: 81)

Pendasaran dan sistem nilai, serta tema tentang "hati-budi" Melayu, setidaknya memberikan gambaran bahwa dua persoalan ini akan selalu menapak dan menjejak di dalam sejarah dan dinamika budaya Melayu, tanpa harus terjebak pada unsur predikatif yang terbatas dan membatas. Penambatan maksim adat ke dalam formula ABSSBK dan kemudian diikuti dengan pengolongan adat menjadi tiga bagian yang menapak sebagai sistem nilai dan bersifat hierarkis merupakan petanda keikutsertaan masyarakat Melayu dalam arus besar peradaban Islam yang sejak awal telah dimulai melalui peralihan sistem tulisan, dari Sanskerta ke Jawi. Realitas sejarah ini menghadirkan corak budaya Melayu yang berlaku secara luas dan sekaligus menjadi mata-rantai yang memperhubungkan budaya Melayu secara umum. Zainal (2006: 11) mengatakan, bahwa Melayu itu berkait erat dengan nilai budaya dan sejarah panjang, atau pernyataan Wilkinson (1908: 2), the first key to all law is, of course, history.

Pada analisis finalnya, pemahaman baru atas wacana ke-Melayu-an merupakan sebuah "kesadaran kosmis" -meminjam istilah Porath (2012: 15) di saat menerangkan fenomena semangat di lingkungan Orang Sakai- yang diidentifikasi melalui kesamaan nilai, yaitu agama, budaya dan bahasa. Kesadaran ini menjadi penting, karena ini menyangkut persoalan peneguhan akan identitas (nilai-nilai) budaya dan pembentukan karaktek manusia yang berbasis budaya. Wacana ke-Melayu-an akan selalu menghadirkan perbincangan yang secara diskursif memberikan semacam dukungan terhadap suatu budaya dalam keberadaannya di lingkungan masyarakat pengusung.

\section{PENUTUP}

Melayu sebagai suatu entitas budaya muncul dan berkembang dalam jalinan ragam peristiwa yang membentang dalam rentang tiga masa. Animismedinamisme dan Hindu-Budha, serta Islam sebagai sistem keyakinan baru bagi masyarakat Melayu merupakan rangkaian dari fakta sejarah yang turut membertentukan Melayu sebagai entitas budaya. Di antara ketiga sumber pengaruh tersebut, Islam menempati posisi utama dan secara kualitatif maupun kuantitatif memiliki tingkat keterpengaruhan yang besar dari dua lainnya. Namun demikian, kehadiran Islam tidak sertamerta mengenyampingkan pola kepercayaan lama yang menjejak dalam adat dan serangkaian tradisi, melainkan Islam justru memberikan kekuatan baru dan insight bagi kehidupan masyarakat secara luas, terutama dalam aspek penguat-kukuhan budaya dan penata-laksanaan sistem nilai yang ada.

Penguat-kukuhan budaya yang terjadi sejak Islam masuk dan berkembang di lingkungan masyarakat maupun istana merupakan sebuah fenomena yang disebut dengan "pemuncakan budaya" atau fresh culture. Fenomena inilah yang menjadi momen penting dalam rangkaian sejarah dan dinamika budaya Melayu karena dari situ pergerak-an budaya mendapat tempat berpijak dan sekaligus sebagai awal untuk beranjak ke arah kehidupan yang baik secara adat maupun tradisi.

Pengaruh yang ditimbulkan dari peristiwa fresh culture dirasakan secara luas-mendalam karena bersinggungan dengan beberapa persoalan mendasar, baik yang menyangkut dengan persoalan budaya maupun penempatan "hati-budi" sebagai locus pengetahuan. Implikasi yang terlihat dari aspek budaya adalah peralihan sistem tulisan Sanskerta ke Jawi, penambatan maksim adat ABSSBK, penggolongan adat menjadi tiga bagian. Peristiwa-peristiwa inilah yang sesungguhnya menjadi bagian penting dari wacana ke-Melayu-an yang digulirkan dan untuk selanjutnya merupakan perajut dari ikatan ke-Melayu-an yang ada. Wacana ke-Melayu-an sesungguhnya merupakan persoalan yang senantiasa terkait dengan beberapa masalah mendasar, seperti penguatan karakter dan pembentukan insan-insan terdidik dan terbina 
secara budaya. Pada sisi inilah karakter ke-Melayuan bermula dan ditumbuh-kembangkan, Melayu yang selalu terhubung dan terpaut ("hati") dengan segenap entitas yang lintas-batas realitas; Melayu yang terjenihkan ("budi") bahwa realitas selalu mengandaikan keterpautan dalam membentuk harmoni untuk suatu keseimbangan: atas-bawah, kiri-kanan, depan-belakang.

* tulisan ini merupakan bagian dari Disertasi yang berjudul Makna 'Menjadi Orang" dalam Budaya Melayu Riau: Perspektif Filsafat Manusia di Program Doktoral Ilmu Filsafat, Fakultas Filsafat, Universitas Gadjah Mada, Yogyakarta, dan telah diubah-suai untuk keperluan publikasi di jurnal.

\section{DAFTAR PUSTAKA}

Abdullah, Taufik. 1989. "Islam dan Pembentukan Tradisi di Asia Tenggara: sebuah Perspektif Perbandingan," dalam Taufik Abdullah dan Sharon Siddique (Eds), Tradisi dan Kebangkitan Islam di Asia Tenggara, Jakarta: LP3S).

Ahmad, A. Samad (Peny.). 2006. Sulalatus Salatin (Sejarah Melayu), Edisi Pelajar, Kuala Lumpur: Dewan Bahasa dan Pustaka.

Alam, M.T. Soetan Lembang. 1920. Berbagai-bagai Kepertjajaan Orang Melajoe, Seri No. 260a, Jakarta: Balai Pustaka.

Ali Haji, Raja. 2002. Gurindam 12 (the Twelve Aphorism), Alih Aksara dan terjemahan oleh Aswandi Ariyoes, Tanjung Pinang: Yayasan Khasanah Melayu.

Al-Attas, Syed Muhammad Naquib. 1990. Islam dalam Sejarah dan Kebudayaan Melayu, Cetakan ke-4, Bandung: Mizan.

Al-Ghazali, 1910. The Alchemy of Happiness, Trans. Claud Field, London: John Murray.

Al-Helmy, Burhanuddin. 1963. Asas Falsafah Kebangsaan Melayu, Djakarta: Penerbit Tekad.

Andaya, Barbara Watson dan Leonard Y. Andaya, 1982, A History of Malaysia, London: Macmillan Education Ltd.
Andaya, Barbara Watson. 1993. To Live as Brothers: Southeast Sumatra in the Seventeenth and Eighteenth Centuries, Honolulu: University of Hawaii Press.

1997. "Recreating a

Vision: Daratan and Kepulauan in Historical Context," in BKI, Riau in transition 153, No. 4, pp. 483-508.

Andaya, Leonard Y. October 2001. "The Search for the 'Origins' of Melayu," in JSEAS, Vol. 32 (3), pp 315-330.

Arnold, Matthew. 2006. Culture and Anarchy, New York: Oxford University Press.

Bakker, Anton dan Achmad Charris Zubair. 1990. Metodologi Penelitian Filsafat, Yogyakarta: Kanisius.

Bertens, K. 1994. Etika, Jakarta: Gramedia.

Binford, Lewis R. 1965. "Archaeological Systematics and the Study of Culture Process," in American Antiquity, Vol. 31, No. 2, Part 1, pp. 203-210.

Blagden, C. Otto. 1899. "The Name 'Malayu'," in JMBRAS, No. 32, pp. 211-213.

Boellstorff, Tom, 2002, "Ethnolocality," in The Asia Pacific Journal of Anthropology, 3 (1), pp. 2448.

Braginsky, V.I. 1993. Tasawnf dan Sastera Melayu: Kajian dan Teks-teks, Jakarta: Seri Publikasi Bersama Pusat Pembinaan dan Pengembangan Bahasa-Universitas Leiden.

1998. Yang Indah, Berfaedah dan Kamal: Sejarah Sastra Melayu dalam Abad ke-719, dialihbahasakan oleh Hersri Setiawan, Jakarta: INIS.

Casparis, Johannes Gijsbertus de. 1985. "Srivijaya and Malayu," in Final Report SPAFA: Consultative Workshop on Archaeological and Environmental Studies on Srivijaya, 16-30 September, pp. 245-255. 
Casparis, Johannes Gijsbertus de. 1992. "Melayu dan Adityawarman," makalah dalam Seminar Sejarah Melayu Kuno, Jambi, 07-08 Desember 1992, Pemda. Tk. I Jambi dan Kantor Wilayah Departemen Pendidikan dan Kebudayaan Jambi, pp. 235-256.

Chambert-Loir. Henri. 2009. "Tulisan Melayu/Indonesia: Aksara dalam Perkembangan Budaya," dalam Henri Chambert-Loir (Ed), Sadur: Sejarab Terjemahan di Indonesia dan Malaysia, Jakarta: Kepustakaan Populer Gramedia, pp. 185-206.

Chou, Cynthia Gek-Hua. 2006. "Reconceptualizing Southeast Asian Studies," in Cynthia Gek-Hua Chou and Vincent Houben, Southeast Asian Studies: Debates and New Directions, Singapore: IIAS and ISEAS, pp. 123-139.

Coedés, George. 1975. The Indianized States of Southeast Asia, Walter F. Vella (Ed) and Susan Brown Cowing (Trans.), Canberra: Australian National University Press.

Davey, Nicholas. 2006. Unquiet Understanding Gadamer's Philosophical Hermenentics, New York: State University of New York Press.

Drakard, Jane, 1993, “A Kingdom of Words: Minangkabau Sovereignty in Sumatran History," Ph.D. Thesis, Australian National University.

Driyarkara. 2006. Karya Lengkap Drijarkara, A. Sudiarja, dkk. (Peny.), Jakarta: Gramedia.

Effendy, Tenas. 1986. Peranan Dukun, Pawang, Bomo, dan Kemantan dalam Kehidupan Orang Melayu di Riau.

2005a. Ungkapan Tradisional Melayu Riau, Edisi Kedua, Kuala Lumpur: Dewan Bahasa dan Pustaka.

2005b. Tegak Menjaga Tuah, Duduke Memelihara Marwah, Makmur Hendrik, dkk., (Peny.), Yogyakarta: Balai Kajian dan Pengembangan Budaya Melayu.
Effendy, Tenas. 2010. Ungkapan Melayu, Pemahaman dan Masalahnya, Pekanbaru: Tenas Effendy Foundation bekerjasama dengan Pemerintah Kota Pekanbaru dan Akademi Pengajian Melayu Universiti Malaya.

2011. "Menelusuri Keselarasan dan Keserasian Budaya Melayu Riau dengan Budaya Minangkabau," makalah yang disampaikan pada Seminar Adat dan Budaya Minangkabau yang diselenggarakan oleh Ikatan Keluarga Minang Riau (IKMR) di Pekanbaru, tanggal 29 Januari 2011.

\section{Kearifan Pemikiran Melayu,}

Pekanbaru: Tenas Effendy Foundation bekerjasama dengan Pemerintah Provinsi Riau.

\section{Pemimpin dalam Ungkapan}

Melayu, Cetakan Ketiga, Pekanbaru: Lembaga Adat Melayu Riau.

Errington, J. Joseph. 2000. "Ideology," in Journal of Linguistic Anthropology, Vol. 9 (1-2), pp. 115117.

Espagne, Michel. 2014. "Bildung," in Barbara Cassin, Dictionary of Untranslatables: A Philosophical Lexicon, Trans. Steven Rendall, et.al., Princeton and Oxford: Princeton University Press, pp. 111-121.

Fang, Liaw Yock. 2011. Sejarah Kesusastraan Melayu Klasik, Jakarta: Yayasan Pustaka Obor Indonesia.

Fischer, H. Th. 1946. "Heathenism and Popular Religion," in W.H. van Helsdingen and H. Hoogenberk (Eds), Cultural Treasures of the East Indies, New York: The Netherlands Information Bureau, A Government Agency of the Kingdom of the Netherlands, pp. 2836.

Furniss, Graham. 2004. Orality: The Power of the Spoken Word, Macmillan: Palgrave.

Gadamer, Hans-Georg. 2004. Truth and Method, Second Revised Edition, Translation revised 
by Joel Weinsheimer and Donald G. Marshall, London \& New York: Continuum.

Geertz, Clifford. 1973. The Interpretations of Cultures: Selected Essays, New York: Basic Books, Inc.

Goddard, Cliff. 2001. "Hati: A Key Word in the Malay Vocabulary of Emotion," in Jean Harkins and Anna Wierzbicka (eds), Emotions in Crosslinguistic Perspective. Berlin: Mouton de Gruyter. 167-195.

Gusmao, Martinho G. Da Silva. 2012. Hans-Georg Gadamer: Penggagas Filsafat Hermeneutik Modern yang Mengagungkan Tradisi, Yogyakarta: Kanisius.

Habermas, Jurgen. 1988. Legitimation Crisis, trans. by Thomas McCarthy, Cambridge: Polity Press.

Hadi W.M., Abdul. 2008. Hermenentika Sastra Barat dan Timur, Jakarta: Pusat Bahasa, Depdiknas.

Hadot, Pierre. 1995. Philosophy as a Way of Life, Trans. Michael Chase, Oxford: Blackwell Publishers.

Hallen, Barry. June 2010. "Ethnophilosophy Redefined?" in Thought and Practice: A Journal of the Philosophical Association of Kenya (PAK), New Series, Vol. 2 No.1, pp. 73-85.

Hamidy, UU. 1986. Membaca Kebidupan Orang Melayu, Pekanbaru: Bumi Pustaka. Pekanbaru: UIR Press.

Pekanbaru: UNRI Press.

1999a. Islam dan Masyarakat Melayu di Riau, Pekanbaru: UIR Pres.

1999b. Dukun Melayu Rantau Kuantan, Pekanbaru: Universitas Lancang Kuning Press.

2014. Jagad Melayu dalam Lintasan Budaya di Riau, Cetakan ke-9, Pekanbaru: Bilik Kreatif Press.
Hamkaz, Ismail. 2012. Potatah Potitih Lubak Kepenuban, Rokan Hulu: Dinas Kebudayaan dan Pariwisata Kabupaten Rokan Hulu.

Hardiman, Budi F. 2015. Seni Memahami: Hermeneutik dari Schleiermacher sampai Derrida, Yogyakarta: Kanisius.

Harris, Marvin. 1976. "History and Significance of the Emic/Etic Distinction," in Annual Review of Anthropology, Vol. 5 (1), pp. 329-350.

Hasbullah, dkk. 2014. Togak Balian: Ritual Pengobatan Masyarakat Kenegerian Koto Rajo, Kuantan Singingi, Pekanbaru: Asa Riau.

Hidayah, Zulyani, 1996, Ensiklopedi Suku Bangsa di Indonesia, Jakarta: LP3S.

Iannone, A. Pablo. 2001. Dictionary of World Philosophy, London: Routledge.

Ikram, Achadiati, dkk., 1985, Kamus MelayuIndonesia, Jakarta: Pusat Pembinaan dan Pengembangan Bahasa, Depdikbud.

Ju Lan, Thung, dkk., 2010, Klaim, Konstestasi dan Konflik Indonesia: Lokalitas vis-a-vis Nasionalitas, Jakarta: Institut Antropologi Indonesia (IAI).

Junaidi-Syam. 2012. Sejarah Kerajaan Lima Lubak, Pasirpengarayan: Disbudpar Rokan Hulu.

Junaidi-Syam, dkk. 2013. Tiga Lorong: Tegub Berdiri di Tengah Persimpangan Riuh Ramai, Pekanbaru: UNRI Press.

Kadir, Mohd. Daud, 2007, "Saling Menghormati dan Saling Memberi pada Orang Melayu Riau" dalam Koentjaraningrat, dkk., Masyarakat Melayu dan Budaya Melayu dalam Perubahan, Heddy Shri Ahimsa-Putra (Ed.), Yogyakarta: Balai Kajian dan Pengembangan Budaya Melayu bekerjasama dengan Adicita Karya Nusa, hlm. 477-500.

Kaelan. 2012. Metode Penelitian Kualitatif Interdisipliner Bidang Sosial, Budaya, Filsafat, Seni, Agama, dan Humaniora, Penerbit Paradigma: Yogyakarta. 
Kang, Yoonhee, 2005, "Untaian Kata Leluhur: Marjinalitas, Emosi dan Kuasa Kata-kata Magi di Kalangan Orag Petalangan Riau," dalam Seri Monograf Kajian, Vol. 1, No. 1, pp. 3-199.

Kapferer, Bruce. 1988. Legends of People, Myths of State: Violence, Intolerance, and Political Culture in Sri Lanka and Australia, Washington: Smithsonian Institution Press.

Kathirithamby-Wells, J. 1993, Hulu-Hilir Unity and Conflict: Malay Statecraft in East Sumatra before Mid-Nineteenth Century," in Archipel, Vol. 45, pp. 77-96.

Kato, Tsuyoshi. 1997. "The Localization of Kuantan in Indonesia: from Minangkabau Frontier to a Riau Administrative District," in BKI, Riau in Transition 153, No. 4, pp. 737763.

Koentjaraningrat, dkk. 1984. Kamus Istilah Antropologi, Jakarta: Pusat Pembinaan dan Pengembangan Bahasa, Depdikbud.

Koentjaraningrat. 1989. Pengantar Ilmu Antropologi, 1989, Jakarta: Aksara Baru.

2004. Kebudayaan, Mentalitas dan Pembangunan, Jakarta: Gramedia.

Kozok, Uli. 2006. Kitab Undang-Undang Tanjung Tanah: Naskah Melayu yang Tertua, Alih Aksara Hassan Djafar, Ninie Susanti dan Waruno Mahdi, dialihbahasakan oleh Achadiati Ikram, dkk., Jakarta: Yayasan Naskah Nusantara dan Yayasan Obor Indonesia.

Kukushkin, Sergei. 2004. "Hikayat Negeri Jambi: The Structure and Sources of a NineteenthCentury Malay Historical Work," in Indonesia and the Malay World, Vol. 32, No. 92, pp. 53-61.

Lapian, A.B. 1992. "Jambi dalam Jaringan Pelayaran dan Perdagangan," makalah dalam Seminar Sejarah Melayu Kuno, Jambi, 07-08 Desember 1992, Pemda. Tk. I Jambi dan Kantor Wilayah Departemen Pendidikan dan Kebudayaan Jambi, pp. 143-149.
Lawn, Chris, and Niall Keane. 2011. The Gadamer Dictionary, London: Continuum International Publishing Group.

Lett, James. 1990. "Emics and Etics: Notes on the Epistemology of Anthropology," in Thomas N. Headland, Kenneth L. Pike and Marvin Harris (Eds), Emics and Etics: The Insider/Outsider Debate, California: SAGE Publication.

Lim, Kim Hui, 2003, "Budi as the Malay Mind: A Philosophical Study of Malay Ways of Reasoning and Emotion in Peribahasa," Ph.D. Thesis, German: University of Hamburg.

Lombard, Denys. 2005. Nusa Jawa: Silang Budaya (Kajian Sejarah Terpadu), Bagian I, Batas-Batas Pembaratan, Cetakan ke-3, diterjemahkan oleh Winarsih Partaningrat Arifin, Rahayu S. Hidayat dan Nini Hidayati Yusuf, Jakarta: Gramedia.

Magnis-Suseno, Franz. 1987. Etika Dasar: Masalahmasalah Pokok Filsafat Moral, Yogyakarta: Kanisius.

2003. Etika Jawa: sebuah Analisa Falsafi tentang Kebijaksanaan Hidup Jawa, Cetakan ke-9, Jakarta: Gramedia.

Manguin, Pierre-Yves, 1993, "Palembang and Sriwijaya: An Early Malay Harbour-City Rediscovered," in JMBRAS, Vol. 66, Part 1 (264), pp. 23-46.

Marsden, William. 1811. The History of Sumatra: Containing An Account of the Government, Laws, Customs, and Manner of the Native Inhabitants with $A$ Description of the Natural Productions and $A$ Relation of the Ancient Political State of that Island, Third Edition, London: Printed for the Author.

Masolo, D. A. 2003. "Philosophy and Indigenous Knowledge: An African Perspective," in Africa Today, Vol. 50, Number 2, Fall/Winter 2003, pp. 21-38. 
Matheson, Virginia, 1979, "Concepts of Malay Ethos in Indigenous Malay Writing," in JSEAS, Vol. 10, No. 2, pp. 351-371.

Miksic, John N. 1987. "From Sri Vijaya to Melaka 'Batu Tagak' in Historical and Cultural Context," in JMBRAS, Vol. 60, Part 2 (253), pp. 1-42.

Milner, Anthony Crothers. 2008. The Malays: Peoples of South-East Asia and the Pacific, Oxford: WileyBlackwell.

2010, Race or Civilization: The Localizing of 'The Malays', Bangi: Institute of Malaysian and International Studies.

Monier-William, Sir, 1956, A Sanskrit-English Dictionary: Etymologically and Philologically Arranged, Oxford: At the Clarendon Press.

Morin, Olivier. 2016. How Traditions Live and Die, Oxford: Oxford University Press.

Musa, Hashim Haji. 2008. Hati Budi Melayu: Pengukuban Menghadapi Cabaran Abad ke-21, Serdang: Penerbit Universiti Putra Malaysia.

Mutalib, Hussin. 1990. Islam and Ethnicity in Malay Politics, Kuala Lumpur: Oxford University.

Nasroen, M., 1957(?). Dasar Falsafah Adat Minangkabau, Djakarta: Penerbit Pasaman.

Osman, Mohd. Taib. 1988. Bunga Rampai: Aspects of Malay Culture, Kuala Lumpur: Dewan Bahasa dan Pustaka.

orang Melayu: suatu Transformasi Budaya," dalam Ahmad Ibrahim, Sharon Siddique dan Yasmin Hussain (Peny.), 1989, Islam di Asia Tenggara: Perspektif Sejarah, Jakarta: LP3ES, pp. 89-97.

Palmer, E. 2005. Hermeneutika: Teori Baru Mengenai Interpretasi, Yogyakarta: Pustaka Pelajar.

Peursen, C.A. van. 2003. Menjadi Filsuf: Suatu Pendorong ke Arah Berfilsafat Sendiri, Yogyakarta: Penerbit Qalam.
Polo, Marco, 1903 The Book of Ser Marco Polo, Vol. II, Trans. and Edited with Noted by Henry Yule, in Two Volumes, London: John Murray.

Porath, Nathan, 2012, Ketika Burung itu Terbang: Therapi Shamanis dan Pemeliharaan Batas-batas Duniawiyah di Kalangan Orang Sakai Riau, dialihbahasakan oleh Sita Rohana, Pekanbaru: Gurindam Press bekerjasama dengan Asosiasi Tradisi Lisan (ATL) Riau.

Pranarka, A.M.W., dan Anton Bakker (Eds). 1979. Epistemologi, Kebudayaan dan Pendidikan: Suatu Simposium Filsafat, Yogyakarta: Kelompok Studi Filsafat.

Pusat Bahasa. 2008. Kamus Bahasa Indonesia, Jakarta: Pusat Bahasa Departemen Pendidikan Nasional.

Rab, Tabrani. 2007. "Kepribadian Melayu," dalam Koentjaraningrat, dkk., Masyarakat Melayu dan Budaya Melayu dalam Perubahan, Heddy Shri Ahimsa-Putra (Ed), Yogyakarta: Balai Kajian dan Pengembangan Budaya Melayu bekerjasama dengan Adicita Karya Nusa, hlm. 453-476.

Reid, Anthony. 2011. Menuju Sejarah Sumatra: Antara Indonesia dan Dunia, dialihbahasakan oleh Masri Maris, Jakarta: Yayasan Pustaka Obor Indonesia dan KITLV-Jakarta.

Rahman, Elmustian, dkk. 2010. Riau Tanah Air Kebudayaan Melayu, Pekanbaru: Pusat Penelitian Kebudayaan dan Kemasyarakatan Universitas Riau.

Schwartz, Gary R., and Linda G.S. Russek, 1998, "Pengantar," dalam Paul Pearsall, The Heart's Code: Tapping the Wisdom and Power of Our Heart Energy, New York: Broadway Books.

Shellabear, W. G. (Peny.), 1896, Sejarah Melayu, Edisi Tulisan (Aksara) Jawi, Singapore: American Mission Press.

Shihab, M. Quraish. 2007. Wawasan al-Qur'an: Tafsir Tematik atas Pelbagai Persoalan Umat, Edisi ke-2, Bandung: Mizan Pustaka. 
Smith, Nicholas H. 1997. Strong Hermeneutics: Contingency and Moral Identity, London: Routledge.

Sudjiman, Panuti HM. 1983. Adat Raja-Raja Melayu: A Critical Edition Together with A Commentary on Court Ceremonials Described, Jakarta: UI Press.

Supadjar, Damardjati, 1993, Nawangsari, Yogyakarta: Media Widya Mandala.

Suwardi, MS., dkk. 2011. Hukum Adat Melayu Riau, Pekanbaru: Alaf Riau.

Swettenham, Frank A. 1895. Malay Sketches, New York: Macmillan \& Co.

Syari'ati, Ali. 1990. Ideologi Kaum Intelektual: Suatu Wawasan Islam, diterjemahkan dan disunting oleh Syafiq Basri dan Haidar Baqir, Bandung: Mizan.

Taslim F. Datuk Mogek, dan Junaidi-Syam. 2007. Trombo Rokan: Buku Besar Alam Manusia dan Budaya Melayu Rokan, Dua Jilid, Pasirpengarayan (Rokan Hulu): Yayasan Garasibumy.

Teeuw, A. 1952. "Pengantar," dalam Abdullah ibn Abdulkadir Munsji, Sedjarah Melaju, Djakarta: Penerbit Djambatan.

1991. "Sejarah Bahasa Melayu," dalam Harimurti Kridalaksana (Ed), Masa Lampan Babasa Indonesia: sebuah Bunga Rampai, Yogyakarta: Kanisius, pp. 110-132.

Toynbee, Arnold. 1947. A Study of History, A Bridgement of Volumes I-VI by. D.C. Somervell, London: Oxford University Press.

Umar, Said, dkk. 1977. Adat Istiadat Daerah Riau, Jakarta: Proyek Penelitian dan Pencatatan Kebudayaan Daerah, Depdikbud.

Veith, Jerome, 2015. Gadamer and the Transmission of History, Indiana: Indiana University Press.

Wee, Vivienne. 1985. "Melayu: Hierarchies of Being in Riau," Ph.D. Thesis, Australian National University.
Wildes, Kevin WM. 2006. "Whose Nature? Natural Law in a Pluralistic World," in Mark J. Cherry, (Ed), The Death of Metaphysics, The Death of Culture: Epistemology, Metaphysics and Morality, Netherlands: Springer, pp. 31-39.

Wilkinson, R.J., 1901, A Malay-English Dictionary, Part 1, Singapore: Kelly \& Walsh Limited.

Wilkinson, R.J. 1908. "Law: Introductory Sketch," in Papers on Malay Subjects, Part 1, Kuala Lumpur: J. Russel at the F.M.S. Government Press.

January 1932. "Some Malay Studies," in JMBRAS, Vol. 10, Part 1 (113), pp. 67-137.

Winstedt, R.O. (Ed). 1938. "The Malay Annals or Sejarah Melayu," Edition Raffles MS 18, in $J M B R A S$, Vol. 16, Part 3 (132), pp. 1-226.

1935. "A History of Malaya," in JMBRAS, Vol. 13, Part 1 (121), pp. iii-270.

Wolters, O.W. 1966. "A Note on the Capital of Śrivijaya During the Eleventh Century," in Artibus Asiae, Vol. 23, Essays Offered to G. H. Luce by His Colleagues and Friends in Honour of His Seventy-Fifth Birthday, pp. 225-239.

1979. "Studying Śrivijaya," in JMBRAS, Vol. 52, Part 2 (236), pp. 1-32.

1990. Kejatuban Srivijaya dalam Sejarah Melayu (The Fall of Srivijaya in Malay History, 1970), dialihbahasakan oleh Toh Kim Hui dan Ranjeet Kaur Khaira, Kuala Lumpur: Dewan Bahasa dan Pustaka.

Yusuf, Yusmar. 2009. Studi Melayu, Jakarta: Wedatama Widya Sastra.

Zainal, Rusli, 2006, "Pidato Pembukaan Musyawarah dan Seminar Lembaga Adat Melayu se-Sumatera: Pentingnya Kerjasama Lembaga Adat Melayu antara Provinsi seSumatera melalui Sekreatariat Bersama," dalam Suwarto, dkk., (Eds), Mengangkat Keberadaan Hak-Hak Tradisional Masyarakat 
Irwandra, dkk. Diskursus The Malays dan Malayness:...

Adat Rumpun Melayu se-Sumatera, Pekanbaru: Lembaga Adat Melayu Riau dan UNRI Press, pp. 7-20.

Zakaria, Iskandar, dkk., 1989, Penelitian dan Pengkajian Naskah Kuno Daerah Jambi, Vol. II, Jakarta: Dir. Sejarah dan Nilai Tradisional, Depdiknas.

Zoetmulder, P.J., 1991, Manunggaling Kawula Gusti: Pantheisme dan Monisme dalam Sastra Suluk Jawa, dialihbahasakan oleh Dick Hartoko, Jakarta: Gramedia. 